\title{
Epigenetic Biomarkers in Colorectal Cancer Patients Receiving Adjuvant or Neoadjuvant Therapy: A Systematic Review of Epidemiological Studies
}

\author{
Martina Barchitta ${ }^{1}\left(\mathbb{D}\right.$, Andrea Maugeri $^{1}{ }^{1}$, , Giovanni Li Destri $^{1}$, Guido Basile $^{2}$ and \\ Antonella Agodi 1,*(D) \\ 1 Department of Medical and Surgical Sciences and Advanced Technologies "GF Ingrassia", University of \\ Catania, via S. Sofia, 87, 95123 Catania, Italy \\ 2 Department of General Surgery and Medical-Surgical Specialties, University of Catania, via S. Sofia, 78, \\ 95123 Catania, Italy \\ * Correspondence: agodia@unict.it
}

Received: 24 June 2019; Accepted: 2 August 2019; Published: 6 August 2019

check for updates

\begin{abstract}
Colorectal cancer (CRC) represents the third-most common cancer worldwide and one of the main challenges for public health. Despite great strides in the application of neoadjuvant and adjuvant therapies for rectal and colon cancer patients, each of these treatments is still associated with certain adverse effects and different response rates. Thus, there is an urgent need for identifying novel potential biomarkers that might guide personalized treatments for specific subgroups of patients. However, until now, there are no biomarkers to predict the manifestation of adverse effects and the response to treatment in CRC patients. Herein, we provide a systematic review of epidemiological studies investigating epigenetic biomarkers in CRC patients receiving neoadjuvant or adjuvant therapy, and their potential role for the prediction of outcomes and response to treatment. With this aim in mind, we identified several epigenetic markers in CRC patients who received surgery with adjuvant or neoadjuvant therapy. However, none of them currently has the robustness to be translated into the clinical setting. Thus, more efforts and further large-size prospective studies and/or trials should be encouraged to develop epigenetic biomarker panels for personalized prevention and medicine in CRC cancer.
\end{abstract}

Keywords: DNA methylation; miRNA; prevention; Public Health; Epidemiology; colon cancer; rectal cancer; CIMP

\section{Introduction}

In 2018, colorectal cancer (CRC) accounted for 823,000 and 1,026,000 new cancer cases in women and men, respectively, making it the third-most common cancer worldwide, and one of the main challenges for public health [1]. Although the introduction of colonoscopy has reduced CRC-related mortality in more-developed countries since the 1980s, the number of deaths has increased by approximately 60\% between 1990 and 2013 [2]. Several genetic and environmental factors are crucial in the etiology of CRC by promoting the progressive accumulation of hallmark cancer traits in colon epithelial cells [3,4]. Beyond these factors, a lot of epigenetic modifications-including DNA methylation and aberrant expression of microRNAs (miRNAs) - commonly occur in early neoplastic lesions (e.g., aberrant crypt foci, adenomas and serrated polyps) and CRC, which in turn drive cancer initiation and formation along with gene mutations [5-8]. Epigenetic mechanisms can be defined as hereditary modifications that influence gene expression and the phenotype without changing the genotype. These molecular processes characterize the epigenome, which is dynamic in response to environmental signals, modifiable during normal cell differentiation and heritable in daughter cells [9]. 
In mammals, DNA methylation is regulated by the activity of three DNA methyltransferases (DNMTs) that catalyse the addition of a methyl group to the fifth carbon of the cytosine: while DNMT1 has a maintenance role, DNMT3a and $3 \mathrm{~b}$ are de novo methylases. The DNA methylation process almost occurs within short CpG-rich regions (i.e., CpG islands), which typically contain almost 5-10 CpGs per $100 \mathrm{bp}$ within the $5^{\prime}$ region of genes [10]. In general, cancer cells exhibit hypermethylation of CpG islands in gene promoters, which can result in transcriptional silencing of tumor suppressor genes, and hypomethylation of repetitive genetic elements, which can affect genomic stability [11]. Along with DNA methylation, miRNAs are endogenous, short, noncoding molecules that participate in post-transcriptional gene expression by suppressing the translation of protein-coding genes or by cleaving several messenger RNAs [12]. Indeed, miRNAs are important molecular mechanisms that can control physiological processes (i.e., cell growth, differentiation, stress response, and tissue remodeling) [13-15] and that play a key role in many disease states including CRC [16]. Particularly, in colon epithelium, both genomic and epigenomic instability can promote the accumulation of gene mutations and epigenetic modifications either in oncogenes or tumor suppressor genes, leading to the malignant transformation of colon cells [17-19]. Gene expression is also regulated by dynamic post-translational histone modifications, which may disrupt contacts within and between nucleosomes, recruit non-histone proteins, and affect the chromatin structure [20]. However, their effects depend on the type of modification, the type of amino acid involved and its position in the histone tail. Specifically, histone (de)acetylation and (de)methylation have been well-characterized in CRC patients and extensively reviewed elsewhere [21,22].

Although these molecular features are commonly shared between colon cancer and rectal cancer, the location of the tumor and its stage have implications for treatment. In general, surgery is the gold standard for the management of patients with non-metastasized CRC. In the last two decades, systemic approaches have been also developed, with strides in the application of the neoadjuvant therapy for rectal cancer and the adjuvant therapy for colon cancer [23]. In rectal cancer, neoadjuvant therapy-given as short-course radiotherapy followed by surgery or as chemoradiotherapy with 5-fluorouracil (5-FU) or capecitabine-is recommended for intermediate-stage and advanced-stage patients [23]. While there are no accepted neoadjuvant therapies for colon cancer, the international guidelines recommend adjuvant chemotherapy for high-risk stage II (according to the Union for International Cancer Control (UICC) classification) and for all the stage III tumors [24]. Adjuvant treatment is generally given as a combination of 5-FU plus oxaliplatin: as in the XELOX protocol for oral administration (capecitabine and oxaliplatin), or as in the FOLFOX4 protocol for intravenous administration (leucovorin, 5-FU and oxaliplatin) [23]. In rectal cancer patients, adjuvant chemotherapy with fluoropyrimidines can be given only in those who did not receive preoperative treatment and in the presence of specific risk factors, such as positive resection margins, perforation in the tumor area or defects in the mesorectum [23]. In the metastatic disease, combinations of leucovorin, 5-FU, and either oxaliplatin (FOLFOX protocol) or irinotecan (FOLFIRI protocol) represent the first-line therapies. More recently, the FOLFOXIRI protocol-the combination of leucovorin, 5-FU, oxaliplatin and irinotecan - has been revealed to be efficacious [25].

Each of these treatments can be associated with certain adverse effects and different response rates. It has been recognized that patients receiving neoadjuvant chemoradiotherapy or radiotherapy often exhibit pelvic floor problems [26], with erectile dysfunction in men and dyspareunia in women [27,28]. With regard to chemotherapy, 5-FU is typically well tolerated whereas oxaliplatin and irinotecan are often associated with neutropenia and diarrhea [23]. Despite difficulties in creating an in vitro model, some studies have reported that neoadjuvant and adjuvant therapies might affect epigenetic mechanisms in colorectal cancer cells, determining the response to treatment $[29,30]$. In line with this evidence, several epidemiological studies have investigated epigenetic signatures-especially DNA methylation and miRNA expression-that might guide personalized treatments for subgroups of CRC patients in the forthcoming future [29,30]. However, until now, there have been no biomarkers to predict the manifestation of adverse effects and the response to treatment in these patients. Herein, we 
provide a systematic review of epidemiological studies investigating epigenetic biomarkers in CRC patients receiving neoadjuvant and/or adjuvant therapies, and their potential role for the prediction of outcomes and the response to treatment.

\section{Literature Search}

\subsection{Search Strategy and Selection Criteria}

Two of the Authors (AM and MB) performed a systematic literature search in the PubMed-Medline, EMBASE, and Web of Science databases from inception to January 2019, with no restriction on the language of publication. The following terms were used: ("Neoadjuvant Therapy" OR "Adjuvant Chemotherapy") AND ("Colorectal Neoplasms" OR "Rectal Neoplasms" OR "Colonic Neoplasms") AND ("DNA Methylation" OR "Methylation" OR "MicroRNAs" OR "Histone Code"). The Authors also searched the reference lists of selected articles to identify all relevant studies. The preferred reporting items for systematic reviews and meta-analysis (PRISMA) guidelines were followed [31] (Table S1).

\subsection{Selection Criteria and Data Collection}

Next, two of the Authors (AM and MB) independently selected the retrieved studies if they were consistent with the following criteria: (i) observational and experimental epidemiological studies (ii) on CRC, colon cancer or rectal cancer patients (iii) receiving surgery with neoadjuvant or adjuvant therapies, (iv) which focused on the relationship of DNA methylation, miRNA expression or histone modifications with overall survival, disease-specific survival, disease-free survival, recurrence-free survival, and response to treatment. In contrast, (i) systematic reviews; (ii) abstracts and unpublished studies; (iii) and those with no treated patients were excluded. From each study, the Authors (AM and $\mathrm{MB}$ ) independently extracted the following information: first Author's last name, year of publication, the total number of participants, type of cancer, type of treatment and the number of treated patients, sample source, epigenetic biomarker, and main findings. Any inconsistencies between the two Authors in the study selection and data extraction phases were resolved through discussion with a third Author (AA).

\section{Results}

\subsection{Study Characteristics}

Figure 1 shows the PRISMA flow diagram of study selection. After removing duplicates, a total of 55 articles were retrieved from the databases: five reviews were excluded after reading titles and/or abstracts, while 50 articles underwent full-text screening. According to selection criteria, we excluded one study with no epidemiological design, one study without treated group, and two studies that did not investigate epigenetic mechanisms. Six relevant studies that met the selection criteria were included from the reference lists of selected articles, and therefore the systematic review included a total of 52 studies published since 2003.

Overall, 20 studies were conducted on CRC patients, whereas 23 and 9 studies analyzed rectal cancer or colon cancer, respectively. Among them, 30 studies recruited CRC patients $(n=21)$ or colon cancer patients $(n=9)$ receiving adjuvant therapy, whereas 18 studies were conducted on rectal cancer patients receiving neoadjuvant therapy. Other studies recruited CRC $(n=1)$ or rectal cancer patients $(n=3)$ receiving either neoadjuvant therapy or adjuvant therapy. With respect to epigenetic biomarkers, 26 studies investigated DNA methylation changes in patients receiving neoadjuvant therapy $(n=6)$, adjuvant therapy $(n=18)$, or both $(n=2)$. Instead, other 26 studies investigated miRNA expression in patients receiving neoadjuvant therapy $(n=12)$, adjuvant therapy $(n=12)$, or both $(n=2)$. The majority of these studies analyzed epigenetic biomarkers in tumor tissues $(n=47)$, whereas only five 
studies used serum samples. No studies examined histone modifications and their association with response to adjuvant or neoadjuvant therapies.
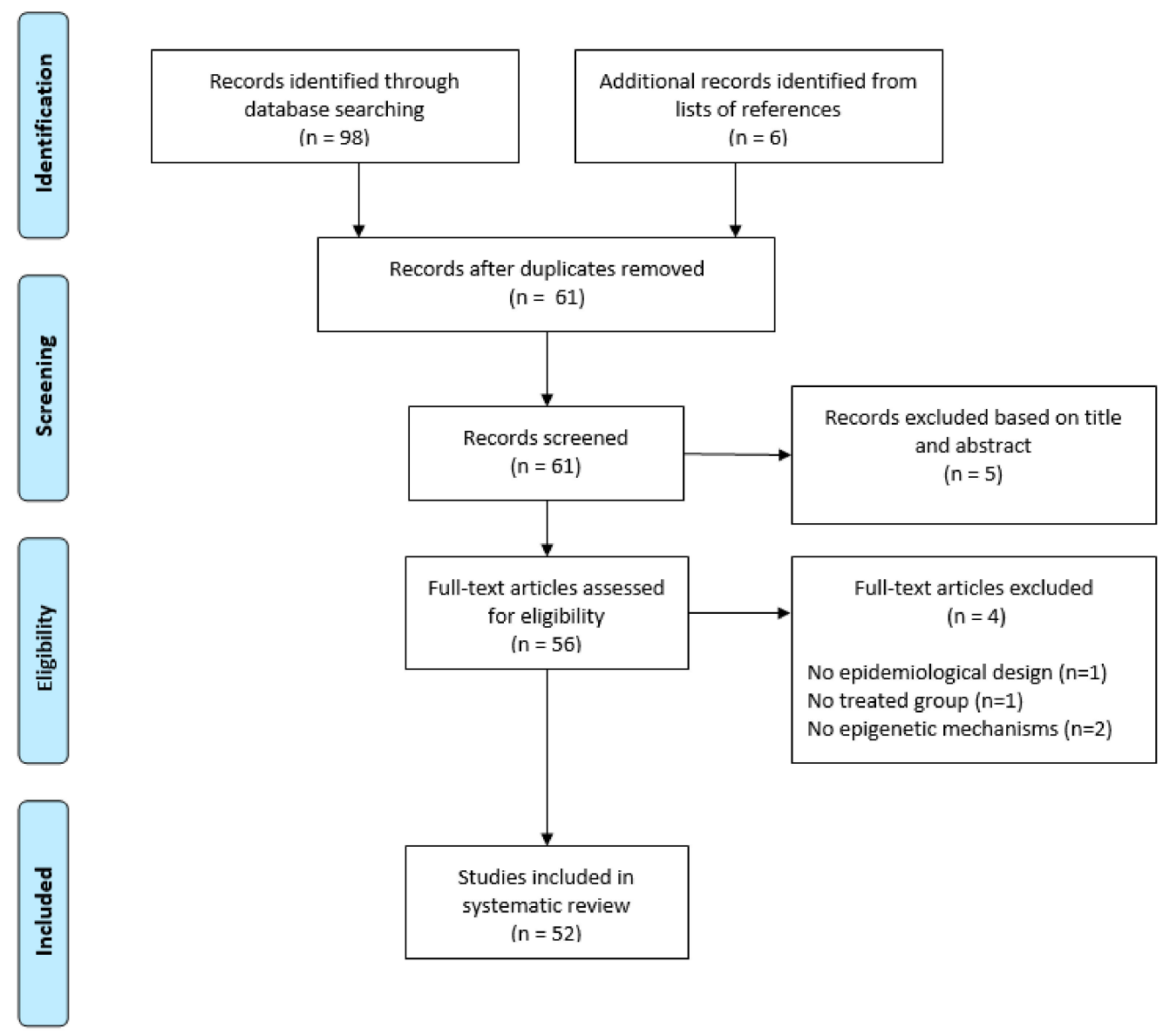

Figure 1. PRISMA 2009 Flow Diagram of study selection.

\subsection{DNA Methylation in Patients Receiving Adjuvant Therapy}

Methylation markers in patients receiving adjuvant therapy-including gene-specific methylation, CpG island methylator phenotype (CIMP), and long interspersed nuclear element-1 (LINE-1) methylation-are discussed in the paragraphs below and the main findings of selected studies are displayed in Tables 1-3.

\subsubsection{Gene-Specific Methylation}

To our knowledge, Nagasaka and colleagues were the first investigating the effect of DNA methylation in CRC patients receiving adjuvant therapy [32]. They found that patients with unmethylated O6-methylguanine-DNA methyltransferase (MGMT) promoter had a higher risk of recurrence within 36 months than those with MGMT hypermethylation. Interestingly, among patients with unmethylated MGMT promoter, those who received adjuvant chemotherapy had an increased risk of recurrence compared with untreated patients [32]. Although the mechanisms underpinning this relationship are currently unclear, the Authors concluded that MGMT hypermethylation might be associated with a lower risk of recurrence in CRC patients receiving adjuvant chemotherapy. A plausible explanation of this relationship is that the silencing of MGMT via promoter methylation, followed by decrease in its DNA repair activity, might enhance the effectiveness of chemotherapy [32]. However, molecular mechanisms that increased the risk of recurrence in patients with unmethylated MGMT promoter are yet to be clarified. In contrast to the above group, Chen and colleagues found no significant association between MGMT methylation and prognosis in CRC patients [33]. They also 
investigated the effect of methylation of the Adenomatous polyposis coli (APC) promoter-a tumor suppressor gene encoding a protein that regulates cell adhesion-demonstrating its association with lower risk of all-causes and CRC-related mortality [33]. Notably, germline APC mutations are one of the main cause of familial adenomatous polyposis, while somatic APC mutations are evident in eight out of 10 sporadic CRCs [34]. However, no interaction between 5-FU adjuvant chemotherapy and MGMT or APC methylation was reported [33].

Another gene that has been investigated is MutL homolog 1 (MLH1), a DNA mismatch repair gene. In 2008, Ide and colleagues first demonstrated that MLH1 expression was down-regulated in CRC tumors that exhibited MLH1 promoter methylation [35]. Next, among patients receiving 5-FU-based adjuvant therapy, they observed that those with reduced MLH1 expression levels had a significantly longer disease-free survival [35]. Methylation of MLH1 promoter can cause defect of the mismatch repair system along with germline mutations in mismatch repair genes including MLH1, MutS homolog 2 (MSH2), MSH6, and Postmeiotic Segregation Increased 2 (PMS2). With this in mind, Sinicrope and colleagues identified two subtypes of colon cancer deficient in mismatch repair based on mismatch repair status and detection of B-Raf Proto-Oncogene (BRAF) V600E or mutations in KRAS Proto-Oncogene (KRAS) [36]. However, the time of disease-free survival was similar between patients deficient in mismatch repair and those without BRAF V600E or KRAS mutations [36]. Over recent years, other methylation markers have been extensively debated. In 2014, Perez-Carbonell and colleagues evaluated the methylation status of Septin 9 (SEPT9), Aristaless-Like Homeobox 4 (ALX4), Twist-related protein 1 (TWIST1), Insulin Like Growth Factor Binding Protein 3 (IGFBP3), Growth Arrest Specific 7 (GAS7), and miR137 in CRC patients, and its association with clinicopathological characteristics [37]. While all genes were hypermethylated in tumor tissues compared with normal adjacent mucosa, only IGFBP3 methylation shortened disease free survival in CRC patients [37]. Interestingly, patients with IGFBP3 hypermethylation did not benefit from 5FU-based adjuvant therapy [37]. However, biochemical and molecular mechanisms that might explain this relationship are currently unknown. In the same year, Heitzer and colleagues aimed to identify novel predictive and prognostic biomarkers in patients randomized to adjuvant chemotherapy with 5-FU and leucovorin or surveillance only [38]. Their survival analysis pointed out that patients receiving adjuvant therapy with no methylation of a combined set of three genes (Protocadherin 10, PCDH10; Secreted Protein Acidic And Rich In Cysteine; SPARC; Ubiquitin C-Terminal Hydrolase L1; UCHL1) had longer overall survival than those with hypermethylation [38]. In the surveillance group, on the contrary, unmethylated genes were associated with shorter disease-free survival and overall survival [38]. Previous studies explained the involvement of these genes in tumor formation and progression. PCDH10 has been recently indicated as a tumor suppressor gene due to its role in cell cycle, tumor progression and metastasis $[39,40]$. Although still debated, SPARC appeared a crucial driver of tumor angiogenesis, cell proliferation and migration [38]. UCHL1 was indicated as a tumor suppressor gene [41], and its methylation might be a prognostic markers in several cancers [42]. In CRC patients receiving adjuvant chemotherapy, Chang and colleagues demonstrated that Homeobox Protein NK-6 Homolog A (NKX6.1) methylation levels were significantly higher in tumor tissues than in adjacent normal mucosa [43]. Next, they showed that NKX6.1 hypermethylation reduced overall survival and disease-free survival [43]. Accordingly, NKX6.1 hypermethylation has been previously reported in cervical cancer [44], acute lymphoblastic leukemia [45], and gastric cancer [46]. In colon cancer patients, Pfütze and colleagues evaluated methylation status of (hyaluronoglucosaminidase 2 protein) HYAL2, a gene encoding HYAL2 with an altered expression in several cancers [47]. In patients receiving 5-FU based adjuvant therapy, HYAL2 hypomethylation improved overall survival and progression-free survival. In patients not receiving adjuvant chemotherapy, on the contrary, HYAL2 hypomethylation seemed to be associated with worse overall survival [47]. 
Table 1. Gene-specific methylation markers in patients receiving adjuvant chemotherapy.

\begin{tabular}{|c|c|c|c|c|c|c|c|c|}
\hline $\begin{array}{l}\text { First Author } \\
\text { and Year }\end{array}$ & Tumor & $\begin{array}{l}\text { Overall } \\
\text { Population } \\
\text { (Treated } \\
\text { Patients) }\end{array}$ & Treatment & Samples & Markers & Methods & Response to Treatment & Other Findings \\
\hline $\begin{array}{l}\text { Nagasaka, T., } \\
2003 \text { [32] }\end{array}$ & $\mathrm{CRC}$ & $90(50)$ & 5-FU & $\begin{array}{c}\text { Tumor and } \\
\text { normal tissues }\end{array}$ & MGMT & MS-PCR & $\begin{array}{l}\text { In the unmethylated group, patients } \\
\text { receiving adjuvant chemotherapy had } \\
\text { greater risk of recurrence than those who } \\
\text { did not receive chemotherapy }\end{array}$ & $\begin{array}{l}\text { Patients with unmethylated MGMT } \\
\text { were more likely to experience } \\
\text { recurrence within } 36 \text { months than those } \\
\text { with MGMT methylation }\end{array}$ \\
\hline $\begin{array}{c}\text { Chen, S.P., } 2009 \\
\text { [33] }\end{array}$ & $\mathrm{CRC}$ & $117(61)$ & 5-FU & Tumor tissues & $\begin{array}{l}\text { APC and } \\
\text { MGMT }\end{array}$ & MS-PCR & $\begin{array}{l}\text { No interaction between adjuvant } \\
\text { chemotherapy and methylation markers } \\
\text { was evident }\end{array}$ & $\begin{array}{l}\text { Patients with APC methylation had } \\
\text { lower risk of death or CRC-related } \\
\text { deaths. No significant association } \\
\text { MGMT methylation and prognosis was } \\
\text { evident }\end{array}$ \\
\hline Ide, T., 2008 [35] & CRC & $94(35)$ & 5-FU & $\begin{array}{l}\text { Tumor and } \\
\text { normal tissues }\end{array}$ & MLH1 & MS-PCR & $\begin{array}{l}\text { Among patients receiving adjuvant } \\
\text { chemotherapy, those with low hMLH1 } \\
\text { mRNA expression levels had longer } \\
\text { disease-free survival }\end{array}$ & $\begin{array}{l}\text { MLH1 mRNA expression levels were } \\
\text { significantly lower in CRC tissues with } \\
\text { MLH1 methylation compared with } \\
\text { unmethylated hMLH1 tissues }\end{array}$ \\
\hline $\begin{array}{c}\text { Sinicrope, F.A., } \\
2015 \text { [36] }\end{array}$ & $\begin{array}{l}\text { Colon } \\
\text { cancer }\end{array}$ & $2720(2720)$ & $\begin{array}{l}\text { mFOLFOX6 } \\
\text { alone or } \\
\text { with } \\
\text { cetuximab }\end{array}$ & Tumor tissues & MLH1 & MS-PCR & Not examined & $\begin{array}{l}\text { Two subtypes of colon cancer deficient } \\
\text { in mismatch repair were identified, } \\
\text { based on mismatch repair status and } \\
\text { detection of BRAFV600E or mutations in } \\
\text { KRAS. However, time of disease-free } \\
\text { survival was similar between patients } \\
\text { deficient in mismatch repair and those } \\
\text { without BRAFV600E or KRAS mutations }\end{array}$ \\
\hline $\begin{array}{l}\text { Perez-Carbonell, } \\
\text { L., } 2014 \text { [37] }\end{array}$ & CRC & $425(425)$ & 5-FU & Tumor tissues & $\begin{array}{l}\text { SEPT9, } \\
\text { TWIST1, } \\
\text { IGFBP3, } \\
\text { GAS7, ALX4 } \\
\text { and miR137 }\end{array}$ & Pyrosequencing & $\begin{array}{l}\text { Patients with IGFBP3 hypermethylation did } \\
\text { not benefit from adjuvant chemotherapy }\end{array}$ & $\begin{array}{l}\text { Methylation levels of all genes analyzed } \\
\text { were significantly higher in tumor } \\
\text { tissues than in normal mucosa. IGFBP3 } \\
\text { hypomethylation was an independent } \\
\text { risk factor for poor disease-free survival }\end{array}$ \\
\hline $\begin{array}{c}\text { Heitzer, E., } 2014 \\
\text { [38] }\end{array}$ & CRC & $143(71)$ & $\begin{array}{l}\text { 5-FU and } \\
\text { leucovorin }\end{array}$ & Tumor tissues & $\begin{array}{l}\text { PCDH10, } \\
\text { SPARC, and } \\
\text { UCHL1, }\end{array}$ & Real-time PCR & $\begin{array}{l}\text { Patients receiving adjuvant therapy with no } \\
\text { methylation of a combined set of three } \\
\text { genes had longer overall survival than those } \\
\text { with hypermethylation. In the surveillance } \\
\text { group, unmethylated genes were associated } \\
\text { with shorter disease-free survival and } \\
\text { overall survival. }\end{array}$ & NA \\
\hline
\end{tabular}


Table 1. Cont.

\begin{tabular}{|c|c|c|c|c|c|c|c|c|}
\hline $\begin{array}{l}\text { First Author } \\
\text { and Year }\end{array}$ & Tumor & $\begin{array}{l}\text { Overall } \\
\text { Population } \\
\text { (Treated } \\
\text { Patients) }\end{array}$ & Treatment & Samples & Markers & Methods & Response to Treatment & Other Findings \\
\hline $\begin{array}{l}\text { Chang, S.Y., } \\
2018 \text { [43] }\end{array}$ & CRC & $151(151)$ & NA & $\begin{array}{l}\text { Tumor and } \\
\text { normal tissues }\end{array}$ & NKX6.1 & MS-PCR & $\begin{array}{l}\text { Patients receiving adjuvant chemotherapy } \\
\text { with NKX6.1 methylation had shorter 5-year } \\
\text { overall survival and disease-free survival } \\
\text { than patients with no NKX6.1 methylation }\end{array}$ & $\begin{array}{c}\text { NKX6.1 methylation was significantly } \\
\text { higher in tumor tissues than in adjacent } \\
\text { normal tissues }\end{array}$ \\
\hline $\begin{array}{c}\text { Pfütze, K., } 2015 \\
\text { [47] }\end{array}$ & $\begin{array}{l}\text { Colon } \\
\text { cancer }\end{array}$ & $232(98)$ & 5-FU & Tumor tissues & HYAL2 & $\begin{array}{l}\text { MALDI-TOF } \\
\text { mass } \\
\text { spectrometry }\end{array}$ & $\begin{array}{l}\text { In patients receiving adjuvant } \\
\text { chemotherapy, low methylation levels were } \\
\text { associated with better overall survival and } \\
\text { progression-free survival. In patients no } \\
\text { receiving adjuvant chemotherapy, on the } \\
\text { contrary, HYAL2 hypomethylation seemed } \\
\text { to be associated with worse overall survival }\end{array}$ & NA \\
\hline \multicolumn{9}{|c|}{$\begin{array}{l}\text { Abbreviations: CRC, Colorectal Cancer; 5-FU, } 5 \text { fluorouracil; MGMT, O6-methylguanine-DNA methyltransferase; MS-PCR, methylation-specific PCR; APC, Adenomatous polyposis coli; } \\
\text { MLH1, MutL homolog 1; BRAF, B-Raf Proto-Oncogene; KRAS, KRAS Proto-Oncogene; SEPT9, Septin 9; ALX4, Aristaless-Like Homeobox 4; TWIST1, Twist-related protein 1; IGFBP3, } \\
\text { Insulin Like Growth Factor Binding Protein 3; GAS7, Growth Arrest Specific 7; PCDH10, Protocadherin 10; SPARC, Secreted Protein Acidic And Rich In Cysteine; UCHL1, Ubiquitin } \\
\text { C-Terminal Hydrolase L1; NA, Not-available; NKX6.1, Homeobox Protein NK-6 Homolog A; HYAL2, Hyaluronoglucosaminidase } 2 \text { protein; MALDI-TOF, Matrix Assisted Laser Desorption } \\
\text { Ionization Time-of-Flight. }\end{array}$} \\
\hline
\end{tabular}




\subsubsection{CpG Island Phenotype}

In 2003, Van Rijnsoever and colleagues investigated the potential of CIMP for predicting prognosis in CRC patients treated with 5-FU adjuvant chemotherapy [48]. In general, CIMP is characterized DNA hypermethylation of genes involved in controlling cell growth and survival. Positive or high-level CIMP (CIMP+ or CIMP-high, according to different classifications) were associated with specific clinicopathological features of CRC, such as mucinous histology of the proximal colon and BRAF mutation [29]. In the study by Van Rijnsoever and colleagues, CIMP+ (based on a panel of three methylation markers including Cyclin Dependent Kinase Inhibitor 2A, Methylated-IN-Tumour locus 2, and Multi Drug Reactivity 1 genes; CDKN2A, MINT-2 and MDR1, respectively) was associated with worse prognosis in CRC patients treated with surgery alone [48]. By contrast, CIMP+ patients receiving adjuvant therapy exhibited improved survival, while no long-term benefits were evident in CIMP- patients [48]. Min and colleagues corroborated this evidence using the Methylight assay to evaluate a panel of five methylation markers (i.e., Calcium Voltage-Gated Channel Subunit Alpha1 G, Insulin Like Growth Factor 2, Neurogenin 1, Runt-Related Transcription Factor 3, and Suppressor Of Cytokine Signaling 1 genes; CACNA1G, IGF2, NEUROG1, RUNX3, and SOCS1, respectively) in CRC patients [49]. They first demonstrated that CIMP-high was also associated with high frequencies of MGMT methylation and microsatellite instability [49]. Moreover, CIMP+ patients receiving adjuvant therapy exhibited increased recurrence-free survival than patients treated with surgery alone, while no benefits from adjuvant therapy were evident in CIMP- or CIMP-low patients [49]. In colon cancer, Shiovitz and colleagues - using the same panel of methylation markers-corroborated that patients with CIMP+ had shorter overall survival than those with CIMP- tumors [50]. They also demonstrated that CIMP+ patients treated with the FOLFIRI protocol had better overall survival than those treated with 5-FU and leucovorin alone. However, benefits of this combination were not reported in patients with CIMP- tumors [50]. Conversely, Cohen and colleagues showed that CIMP+ status based on the same panel of methylation markers did not affect overall survival in CRC patients, but it was associated with right-side tumor location and BRAF mutations [51]. Jover and colleagues used pyrosequencing to analyze an alternative panel of five markers (i.e., CACNAG1, SOCS1, RUNX3, NEUROG1, and MLH1) in CRC patients receiving 5-FU adjuvant therapy [52]. They found an interaction between 5-FU treatment and CIMP status, demonstrating that adjuvant therapy improved disease-free survival in CIMP- but not in CIMP+ patients [52]. Interestingly, in patients not receiving adjuvant therapy, CIMP status was the only predictor of disease-free survival [52]. In 2013, Han and colleagues analyzed CIMP status based on an extended panel of eight markers (i.e., CACNA1G, CDKN2A, IGF2, MLH1, NEUROG1, RUNX3, SOCS1, and Cellular Retinoic Acid Binding Protein 1 - CRABP1) in CRC patients who received adjuvant therapy with the FOLFOX protocol [53]. They showed that CIMP status was associated with microsatellite instability but not with disease-free survival. However, methylation of NEUROG1 and CDKN2A increased the risk of recurrence [53]. Bae and colleagues revised the eight-marker panel for a new CIMP classification system that classified tumors into three different CIMP subtypes (i.e., CIMP-: 0-4 methylated markers, CIMP+1: 5-6 methylated markers and CIMP +2 : 7-8 methylated markers) [54]. Among nearly 1400 CRC patients treated with surgery alone, those with CIMP+1 tumors reported lower cancer-specific survival and relapse-free survival than those with CIMP- and CIMP+2 tumors [54]. Next, the Authors confirmed this finding in a cohort of CRC patients treated with FOLFOX or XELOX protocols [54]. 
Table 2. CpG island methylator phenotype markers in patients receiving adjuvant chemotherapy.

\begin{tabular}{|c|c|c|c|c|c|c|c|c|}
\hline $\begin{array}{l}\text { First Author } \\
\text { and Year }\end{array}$ & Tumor & $\begin{array}{c}\text { Overall Population } \\
\text { (Treated Patients) }\end{array}$ & Treatment & Samples & Markers & Methods & Response to Treatment & Other Findings \\
\hline $\begin{array}{l}\text { Van Rijnsoever, } \\
\text { M., } 2003 \text { [48] }\end{array}$ & CRC & $206(103)$ & $5-\mathrm{FU}$ & Tumor tissues & $\begin{array}{l}\text { CIMP (CDKN2A, } \\
\text { MINT-2 and MDR1) }\end{array}$ & MS-PCR & $\begin{array}{c}\text { CIMP+ patients receiving adjuvant } \\
\text { therapy exhibited improved survival, } \\
\text { while no long-term benefits were evident } \\
\text { in CIMP- patients }\end{array}$ & $\begin{array}{l}\text { CIMP+ was associated with worse } \\
\text { prognosis in patients treated with } \\
\text { surgery alone }\end{array}$ \\
\hline $\begin{array}{c}\text { Min, B.H., } 2011 \\
\text { [49] }\end{array}$ & CRC & $245(124)$ & $\begin{array}{l}\text { 5-FU or } \\
\text { capecitabine }\end{array}$ & Tumor tissues & $\begin{array}{l}\text { CIMP (CACNA1G, } \\
\text { IGF2, NEUROG1, } \\
\text { RUNX3, and SOCS1) }\end{array}$ & $\begin{array}{c}\text { MethyLight } \\
\text { assay }\end{array}$ & $\begin{array}{l}\text { CIMP+ patients receiving adjuvant } \\
\text { therapy exhibited increased } \\
\text { recurrence-free survival than patients } \\
\text { treated with surgery alone, while no } \\
\text { benefits from adjuvant therapy were } \\
\text { evident in CIMP- or CIMP-low patients }\end{array}$ & $\begin{array}{l}\text { CIMP-high was also associated with } \\
\text { high frequencies of MGMT } \\
\text { methylation and microsatellite } \\
\text { instability }\end{array}$ \\
\hline $\begin{array}{l}\text { Shiovitz, S., } \\
2014 \text { [50] }\end{array}$ & $\begin{array}{l}\text { Colon } \\
\text { cancer }\end{array}$ & $615(316 / 299)$ & $\begin{array}{l}\text { 5-FU and } \\
\text { leucovorin } \\
\text { alone or } \\
\text { with } \\
\text { irinotecan }\end{array}$ & Tumor tissues & $\begin{array}{l}\text { CIMP (CACNA1G, } \\
\text { IGF2, NEUROG1, } \\
\text { RUNX3, and SOCS1) }\end{array}$ & $\begin{array}{l}\text { MethyLight } \\
\text { assay }\end{array}$ & $\begin{array}{l}\text { CIMP+ patients treated with the FOLFIRI } \\
\text { protocol had better overall survival than } \\
\text { those treated with 5-FU and leucovorin } \\
\text { alone. However, benefits of this } \\
\text { combination were not reported in patients } \\
\text { with CIMP- tumors }\end{array}$ & $\begin{array}{l}\text { CIMP+ had shorter overall survival } \\
\text { than those with CIMP- tumors }\end{array}$ \\
\hline $\begin{array}{l}\text { Cohen, S.A., } \\
2016 \text { [51] }\end{array}$ & CRC & $292(144 / 148)$ & $\begin{array}{l}\text { mFOLFOX6 } \\
\text { or XELOX }\end{array}$ & Tumor tissues & $\begin{array}{l}\text { CIMP (CACNA1G, } \\
\text { IGF2, NEUROG1, } \\
\text { RUNX3, and SOCS1) }\end{array}$ & $\begin{array}{l}\text { MethyLight } \\
\text { Assay }\end{array}$ & Not examined & $\begin{array}{l}\text { CIMP+ status did not affect overall } \\
\text { survival, but it was associated with } \\
\text { right-side tumor location and BRAF } \\
\text { mutations }\end{array}$ \\
\hline $\begin{array}{c}\text { Jover, R., } 2011 \\
\text { [52] }\end{array}$ & CRC & $302(93)$ & $5-\mathrm{FU}$ & Tumor tissues & $\begin{array}{l}\text { CIMP (CACNA1G, } \\
\text { SOCS1, RUNX3, } \\
\text { NEUROG1, and } \\
\text { MLH1) }\end{array}$ & Pyrosequencing & $\begin{array}{l}\text { Adjuvant therapy improved disease-free } \\
\text { survival in CIMP- but not in CIMP+ } \\
\text { patients. In patients not receiving } \\
\text { adjuvant therapy, CIMP status was the } \\
\text { only predictor of disease-free survival }\end{array}$ & NA \\
\hline $\begin{array}{c}\text { Han, S.W., } 2013 \\
\text { [53] }\end{array}$ & CRC & $322(322)$ & FOLFOX & $\begin{array}{l}\text { Tumor and } \\
\text { normal tissues }\end{array}$ & $\begin{array}{l}\text { CIMP (CACNA1G, } \\
\text { CDKN2A, CRABP1, } \\
\text { IGF2, MLH1, } \\
\text { NEUROG1, RUNX3 } \\
\text { and SOCS1) }\end{array}$ & $\begin{array}{l}\text { MethyLight } \\
\text { assay }\end{array}$ & Not examined & $\begin{array}{c}\text { CIMP status was associated with } \\
\text { microsatellite instability but not with } \\
\text { disease-free survival. Methylation of } \\
\text { NEUROG1 and CDKN2A increased } \\
\text { the risk of recurrence }\end{array}$ \\
\hline $\begin{array}{l}\text { Bae, J.M., } 2017 \\
{[54]}\end{array}$ & CRC & $1370(531 / 365 / 49)$ & $\begin{array}{l}\text { 5-FU and } \\
\text { leucovorin, } \\
\text { FOLFOX, or } \\
\text { FOLFIRI }\end{array}$ & Tumor tissues & $\begin{array}{l}\text { CIMP (CACNA1G, } \\
\text { CDKN2A, CRABP1, } \\
\text { IGF2, MLH1, } \\
\text { NEUROG1, RUNX3 } \\
\text { and SOCS1) }\end{array}$ & $\begin{array}{l}\text { MethyLight } \\
\text { assay }\end{array}$ & $\begin{array}{l}\text { Among patients treated FOLFOX or } \\
\text { XELOX protocols, CIMP+1 tumors } \\
\text { reported lower cancer-specific survival } \\
\text { and relapse-free survival than those with } \\
\text { CIMP- and CIMP+2 tumors }\end{array}$ & $\begin{array}{l}\text { Among patients treated with surgery } \\
\text { alone, those with CIMP+1 tumors } \\
\text { reported lower cancer-specific surviva } \\
\text { and relapse-free survival than those } \\
\text { with CIMP- and CIMP+2 tumors }\end{array}$ \\
\hline
\end{tabular}




\subsubsection{Long Interspersed Nuclear Element-1 Methylation}

LINE-1 sequences-a class of retrotransposons capable of independent and autonomous retro-transposition via RNA intermediate [55]—account for $\approx 18 \%$ of the human genome, with more than 500,000 copies. Given their abundance throughout the genome, methylation status of these sequences has been widely used as a surrogate marker of global methylation in aging and age-related disease [56-63]. Particularly, a meta-analysis showed that LINE-1 methylation levels were significantly lower in tissue samples from CRC patients than in healthy controls [64]. Indeed, hypomethylation of these elements might be affected by dietary habits and environmental exposures [65-68], thereby increasing the risk of chromosomal instability and aberrant genome function $[69,70]$.

In 2011, Kawakami and colleagues investigated LINE-1 methylation level as a predictive and prognostic marker in CRC patients receiving surgery alone or in combination with 5-FU adjuvant chemotherapy [71]. Since LINE-1 methylation correlated with CIMP status [72], the Authors recruited a subgroup of CIMP- patients. In patients treated with surgery alone, LINE-1 hypomethylation was associated with worse prognosis, whereas it conferred a survival benefit in patients receiving adjuvant therapy [71]. Benefits from adjuvant chemotherapy were not evident in patients with LINE-1 hypermethylation [71]. Next, Chen and colleagues confirmed that LINE-1 methylation was associated with clinicopathological features and recurrence-free survival in CRC patients receiving adjuvant therapy based on the FOLFOX protocol [73]. Similarly, Lou and colleagues reported lower LINE-1 methylation level in colon cancer patients receiving adjuvant therapy with post-therapeutic recurrence than in those without recurrence [74]. Their multivariable analysis confirmed LINE-1 hypomethylation as an independent risk factor of post-therapeutic recurrence. In addition, patients with LINE-1 hypomethylation had reduced disease free survival in the whole cohort and in those with post-therapeutic recurrence after 6 months [74]. 
Table 3. LINE-1 methylation markers in patients receiving adjuvant chemotherapy.

\begin{tabular}{|c|c|c|c|c|c|c|c|c|}
\hline $\begin{array}{l}\text { First Author } \\
\text { and Year }\end{array}$ & Tumor & $\begin{array}{l}\text { Overall Population } \\
\text { (Treated Patients) }\end{array}$ & Treatment & Samples & Markers & Methods & Response to Treatment & Other Findings \\
\hline $\begin{array}{l}\text { Kawakami, K., } \\
2011[71]\end{array}$ & CRC & 155 (94) & 5-FU & Tumor tissues & LINE-1 & $\begin{array}{l}\text { MS-PCR and } \\
\text { Methylight } \\
\text { assay }\end{array}$ & $\begin{array}{l}\text { LINE-1 hypomethylation conferred a } \\
\text { survival benefit in patients receiving } \\
\text { adjuvant therapy. Benefits from } \\
\text { adjuvant chemotherapy were not } \\
\text { evident in patients with LINE-1 } \\
\text { hypermethylation }\end{array}$ & $\begin{array}{l}\text { In patients treated with } \\
\text { surgery alone, LINE-1 } \\
\text { hypomethylation was } \\
\text { associated with worse } \\
\text { prognosis }\end{array}$ \\
\hline $\begin{array}{c}\text { Chen, D., } 2016 \\
\text { [73] }\end{array}$ & CRC & 336 (NA) & $\begin{array}{l}\text { FOLFOX-4 or } \\
\text { mFOLFOX-6 }\end{array}$ & Tumor tissues & LINE-1 & Pyrosequencing & $\begin{array}{l}\text { LINE-1 methylation was associated with } \\
\text { clinicopathological features and } \\
\text { recurrence-free survival in CRC patients } \\
\text { receiving adjuvant therapy based on the } \\
\text { FOLFOX protocol }\end{array}$ & NA \\
\hline $\begin{array}{c}\text { Lou, Y.T., } 2015 \\
{[74]}\end{array}$ & $\begin{array}{l}\text { Colon } \\
\text { cancer }\end{array}$ & $129(129)$ & FOLFOX-4 & Tumor tissues & LINE-1 & Pyrosequencing & $\begin{array}{l}\text { LINE-1 methylation level was lower in } \\
\text { patients receiving adjuvant therapy with } \\
\text { post-therapeutic recurrence than in } \\
\text { those without recurrence. LINE-1 } \\
\text { hypomethylation as an independent risk } \\
\text { factor of post-therapeutic recurrence }\end{array}$ & $\begin{array}{l}\text { Patients with LINE-1 } \\
\text { hypomethylation had } \\
\text { reduced disease free } \\
\text { survival in the whole } \\
\text { cohort and in those with } \\
\text { post-therapeutic } \\
\text { recurrence after } 6 \text { months }\end{array}$ \\
\hline
\end{tabular}

Abbreviations: CRC, Colorectal Cancer; 5-FU, 5 fluorouracil; LINE-1, Long interspersed nuclear element-1; MS-PCR, methylation-specific PCR. 


\subsection{DNA Methylation in Patients Receiving Neoadjuvant Therapy}

Methylation markers in patients receiving neoadjuvant therapy-including gene-specific methylation, CpG island methylator phenotype, and global or genome-wide methylation-are discussed in the paragraphs below and the main findings of selected studies are summarized in Tables 4-6.

\subsubsection{Gene-Specific Methylation}

In 2010, De Maat and colleagues were the first investigating the prognostic value of DNA methylation in rectal cancer patients receiving neoadjuvant chemoradiation [75]. They found that methylation status of several MINT loci (i.e., MINT3 hypermethylation and MINT17 hypomethylation) reduced the risk of recurrence [75]. Since aberrant methylation of these loci has been also observed in CRC, several groups included them in some alternative CIMP panels. In the following years, few studies evaluated the role of DNA methylation in predicting response to neoadjuvant chemoradiation. Ebert and colleagues demonstrated the association of hypermethylation of the Transcription Factor Activating Protein 2 Epsilon (TFAP2E) gene with non-response to neoadjuvant chemoradiation in rectal cancer patients [76]. In contrast, the odds of adequate response were 6-fold higher in patients with TFAP2E hypomethylation compared with the whole cohort. Next, Molinari and colleagues profiled 24 tumor suppressors genes in tissues from rectal cancer patients receiving neoadjuvant chemoradiotherapy [77]. Compared with adjacent normal tissues, tumor samples exhibited hypermethylation of Estrogen Receptor 1, Cadherin 13, Retinoic Acid Receptor Beta, Cell Surface Adhesion Molecule, and Adenomatous Polyposis Coli (ESR1, CDH13, RARB, IGSF4, and APC) genes [77]. With respect to response to neoadjuvant therapy, however, only Tissue Inhibitor of Metalloproteinases 3 (TIMP3) methylation status was significantly different across four tumor regression grade classes. Particularly, non-responders to neoadjuvant therapy displayed TIMP3 hypomethylation than responders [77]. While the above research groups analyzed DNA methylation in tumor tissues, Sun and colleagues investigated MGMT methylation in cell-free DNA from serum of rectal cancer patients, and its relationship with response to 5-FU-based neoadjuvant chemoradiation [78]. Interestingly, they found that MGMT hypermethylation was associated with improved response to treatment and higher regression compared with MGMT hypomethylation [78].

\subsubsection{CpG Island Methylator Phenotype}

In 2012, Jo and colleagues used methylation specific PCR to examine a panel of 5 CIMP markers (i.e., CACNA1G, IGF2, NEUROG1, RUNX3, and SOCS1) in rectal cancer patients receiving 5-FU-based neoadjuvant chemoradiation [79]. Contrary to other research groups, they reported no association with clinicopathological features, and KRAS or BRAF mutations. Although CIMP+ patients exhibited worse 3-year and 5-year disease-free survival, no association with response to neoadjuvant chemoradiation was evident [79]. Using the same CIMP panel on rectal cancer patients receiving adjuvant or neoadjuvant therapy, Kohonen-Corish and colleagues showed no association of CIMP+ status with overall survival [80]. However, they observed that combination of CDKN2A methylation and KRAS mutations independently predicted the risk of recurrence, thereby reducing overall and cancer-specific survival [80]. 
Table 4. Gene-specific methylation markers in rectal cancer patients receiving neoadjuvant chemoradiation.

\begin{tabular}{|c|c|c|c|c|c|c|c|c|}
\hline $\begin{array}{l}\text { First Author } \\
\text { and Year }\end{array}$ & Tumor & $\begin{array}{l}\text { Overall } \\
\text { Population } \\
\text { (Treated } \\
\text { Patients) }\end{array}$ & Treatment & Samples & Markers & Methods & Response to Treatment & Other Findings \\
\hline $\begin{array}{l}\text { De Maat, M.F., } \\
2010 \text { [75] }\end{array}$ & Rectal cancer & $251(251)$ & Chemoradiation & Tumor tissues & MINT loci & $\begin{array}{l}\text { Absolute } \\
\text { quantitative } \\
\text { assessmen } \\
\text { tof methylated } \\
\text { alleles }\end{array}$ & Not examined & $\begin{array}{l}\text { MINT3 hypermethylation } \\
\text { and MINT17 } \\
\text { hypomethylation } \\
\text { reduced the risk of } \\
\text { recurrence }\end{array}$ \\
\hline $\begin{array}{c}\text { Ebert, M.P., } 2012 \\
\text { [76] }\end{array}$ & Rectal cancer & 220 (NA) & Chemoradiation & Tumor tissues & TFAP2E & MethyLight assay & $\begin{array}{l}\text { TFAP2E hypermethylation was } \\
\text { associated with non-response to } \\
\text { neoadjuvant chemoradiation. The } \\
\text { odds of adequate response were } \\
\text { higher in patients with TFAP2E } \\
\text { hypomethylation compared with the } \\
\text { whole cohort }\end{array}$ & NA \\
\hline $\begin{array}{l}\text { Molinari, C., } \\
2013 \text { [77] }\end{array}$ & Rectal cancer & $74(74)$ & Chemoradiation & Tumor tissues & 24 genes & $\begin{array}{l}\text { Methylation-specific } \\
\text { multiplex } \\
\text { ligation-dependent } \\
\text { probeamplification }\end{array}$ & $\begin{array}{l}\text { In patients receiving neoadjuvant } \\
\text { therapy, TIMP3 methylation status } \\
\text { was significantly different across four } \\
\text { tumor regression grade classes }\end{array}$ & $\begin{array}{c}\text { Compared with adjacent } \\
\text { normal tissues, tumor } \\
\text { samples exhibited } \\
\text { hypermethylation of } \\
\text { ESR1, CDH13, RARB, } \\
\text { IGSF4, and APC genes }\end{array}$ \\
\hline $\begin{array}{c}\text { Sun, W., } 2013 \\
{[78]}\end{array}$ & Rectal cancer & $34(34)$ & Chemoradiation & Serum & MGMT & MS-PCR & $\begin{array}{l}\text { Serum MGMT hypermethylation was } \\
\text { associated with improved response to } \\
\text { treatment and higher regression } \\
\text { compared with MGMT } \\
\text { hypomethylation }\end{array}$ & NA \\
\hline
\end{tabular}

Abbreviations: MINT, Methylated-IN-Tumour loci; TFAP2E, Transcription Factor Activating Protein 2 Epsilon; ESR1, Estrogen Receptor 1; CDH13, Cadherin 13; RARB, Retinoic Acid Receptor Beta; IGSF4, Cell Surface Adhesion Molecule; APC, Adenomatous Polyposis Coli; TIMP3, Tissue Inhibitor of Metalloproteinases 3; MS-PCR, methylation-specific PCR; MGMT,

O6-methylguanine-DNA methyltransferase. 
Table 5. CpG island methylator phenotype markers in rectal cancer patients receiving neoadjuvant chemoradiation.

\begin{tabular}{|c|c|c|c|c|c|c|c|c|}
\hline $\begin{array}{l}\text { First Author } \\
\text { and Year }\end{array}$ & Tumor & $\begin{array}{l}\text { Overall } \\
\text { Population } \\
\text { (Treated } \\
\text { Patients) }\end{array}$ & Treatment & Samples & Markers & Methods & $\begin{array}{c}\text { Response to } \\
\text { Treatment }\end{array}$ & Other Findings \\
\hline Jo, P., 2012 [79] & Rectal cancer & $150(150)$ & Chemoradiation & Tumor tissues & $\begin{array}{l}\text { CIMP (CACNA1G, } \\
\text { IGF2, NEURO1G, } \\
\text { RUNX3, and } \\
\text { SOCS1) }\end{array}$ & $\begin{array}{l}\text { JA1G, } \\
\text { O1G, } \\
\text { nd }\end{array}$ & $\begin{array}{cr}\text { No association } & \mathrm{No} \\
\text { with response to } & \mathrm{Cl} \\
\text { neoadjuvant } & \text { KRA } \\
\text { chemoradiation } & \mathrm{C} \\
\text { was evident } & 3-\mathrm{ye} \\
\end{array}$ & $\begin{array}{l}\text { No association of CIMP status with } \\
\text { clinicopathological features, and } \\
\text { KRAS or BRAF mutations was evident. } \\
\text { CIMP+ patients exhibited worse } \\
\text { 3-year and 5-year disease-free survival }\end{array}$ \\
\hline $\begin{array}{l}\text { Kohonen-Corish, } \\
\text { M.R., } 2013 \text { [80] }\end{array}$ & Rectal cancer & $381(18)$ & Chemoradiation & Tumor tissues & \multicolumn{2}{|c|}{$\begin{array}{l}\text { CIMP (CACNA1G, } \\
\text { IGF2, NEURO1G, } \\
\text { RUNX3, and } \\
\text { SOCS1) and } \\
\text { CDKN2A }\end{array}$} & $\begin{array}{l}\text { No } \\
\text { Com } \\
\text { and } \\
\mathrm{p}\end{array}$ & $\begin{array}{l}\text { No association of CIMP+ status with } \\
\text { overall survival was evident. } \\
\text { Combination of CDKN2A methylation } \\
\text { and KRAS mutations independently } \\
\text { predicted the risk of recurrence, } \\
\text { thereby reducing overall and } \\
\text { cancer-specific survival }\end{array}$ \\
\hline \multicolumn{9}{|c|}{$\begin{array}{l}\text { Abbreviations: CIMP, CpG island methylator phenotype; CACNA1G, Calcium Voltage-Gated Channel Subunit Alpha1 G; IGF2, Insulin Like Growth Factor 2; NEUROG1, Neurogenin 1; } \\
\text { RUNX3, Runt-Related Transcription Factor 3; SOCS1, Suppressor Of Cytokine Signaling 1; MS-PCR, methylation-specific PCR; CDKN2A, Cyclin Dependent Kinase Inhibitor 2A; KRAS, } \\
\text { KRAS Proto-Oncogene. }\end{array}$} \\
\hline $\begin{array}{l}\text { First Author } \\
\text { and Year }\end{array}$ & Tumor & $\begin{array}{l}\text { Overall } \\
\text { Population } \\
\text { (Treated } \\
\text { Patients) }\end{array}$ & Treatment & Samples & Markers & Methods & Response to Treatment & Other Findings \\
\hline $\begin{array}{c}\text { Tsang, J.S., } 2014 \\
\text { [81] }\end{array}$ & Rectal cancer & $53(53)$ & Chemoradiation & Tumor tissues & $\begin{array}{c}\text { Global } \\
\text { methylation }\end{array}$ & $\begin{array}{l}\text { Immunohistochemical } \\
\text { staining and image } \\
\text { analysis of staining }\end{array}$ & $\begin{array}{l}\text { A significant reduction of } \\
\text { global DNA methylation in } \\
\text { the majority of patients. } \\
\text { Global methylation of } \\
\text { pre-treatment specimens was } \\
\text { significantly correlated with } \\
\text { tumor stage and regression }\end{array}$ & $\begin{array}{l}\text { in } \\
\text { vas } \\
\text { ith } \\
\text { on }\end{array}$ \\
\hline $\begin{array}{l}\text { Gaedcke, J., } \\
2014 \text { [82] }\end{array}$ & Rectal cancer & $185(185)$ & Chemoradiation & Tumor tissues & $\begin{array}{l}\text { Whole genome } \\
\text { methylation }\end{array}$ & $\begin{array}{l}\text { Whole genome } \\
\text { methylation CpG } \\
\text { island array }\end{array}$ & Not examined & $\begin{array}{l}\text { In a discovery cohort, } 20 \text { highly } \\
\text { discriminative DMRs were } \\
\text { identified. In two additional } \\
\text { validation cohorts, } 10 \text { DMRs that } \\
\text { allowed the discrimination of } \\
\text { patients with different prognosis } \\
\text { were confirmed }\end{array}$ \\
\hline
\end{tabular}




\subsubsection{Global and Genome-Wide Methylation}

To our knowledge, few studies examined global or genome-wide methylation in rectal cancer patients receiving neoadjuvant chemoradiation. In 2014, Tsang and colleagues compared global DNA methylation between pre- and post-treatment resection specimens, using immunohistochemical staining followed by image analysis [81]. They observed a significant reduction of global DNA methylation in the majority of patients. Moreover, global methylation of pre-treatment specimens was significantly correlated with tumor stage and regression [81]. In the same year, Gaedcke and colleagues used a genome methylation $\mathrm{CpG}$ island array to identify differentially methylated regions (DMRs) that discriminate patients according to their response to treatment [82]. They first identified 20 highly discriminative DMRs in a discovery cohort. Next, in two additional validation cohorts, they confirmed and validated 10 DMRs that allowed the discrimination of patients with different prognosis [82].

\subsection{MicroRNA in Patients Receiving Adjuvant Therapy}

In the last decade, several studies investigated miRNA signatures in CRC patients receiving adjuvant therapy, and their main findings are displayed in Table 7. In 2008, Schetter and colleagues were the first to examine miRNA expression in colon cancer patients receiving 5-FU based adjuvant chemotherapy [83]. They first compared miRNA profiles between tumor tissues and adjacent normal mucosa in a test cohort of Caucasians, identifying 37 differentially expressed miRNAs [83]. Next, they confirmed five miRNAs (i.e., miR-20a, miR-21, miR-106a, miR-181b, and miR-203) that were enriched in tumor tissues from a validation cohort of Asians. Among these miRNAs, miR-21 upregulation was associated with poor survival and poor therapeutic response in both cohorts [83]. This finding was corroborated by Oue and colleagues, which examined miR-21 expression in colon cancers from two independent cohorts of Caucasians and Asians [84]. In both cohorts, upregulation of miR-21 was associated with poor survival independent of clinicopathological features [84]. Interestingly, patients with miR-21 upregulation did not benefit from the adjuvant chemotherapy. In the Asian cohort, patients receiving 5-FU based adjuvant chemotherapy with miR-21 downregulation showed better survival than those with upregulation [84]. More recently, Coebergh van den Braak and colleagues evaluated the prognostic value of a 2-miRNA signature (i.e., let-7i and miR-10b) in colon cancer patients treated with (stage III patients) or without (stage I-II patients) adjuvant chemotherapy [85]. Notably, 2-miRNA signature predicted hepatic recurrence in stage I-II patients. In the same group, the combination with miR-30b also predicted distant metastasis. In contrast, this 2-miRNA signature had no prognostic value in stage III patients receiving adjuvant therapy [85]. In 2011, Ma and colleagues applied a miRNA microarray to CRC patients receiving adjuvant chemotherapy, demonstrating that miR-150 was downregulated in tumors compared with adjacent normal tissues [86]. In addition, they observed that low miR-150 expression levels were associated with reduced overall survival and worse response to treatment [86]. A similar approach was applied by Perez-Carbonell and colleagues that profiled miRNAs in CRC patients receiving 5-FU based adjuvant chemotherapy, using the Affymetrix miRNA expression array [87]. They found that miR-320e was upregulated in patients with recurrence compared with those without recurrence. Moreover, miR-320e upregulation was associated with poor overall and disease-free survival and overall survival [87]. Similarly, Zhang and colleagues used miRNA microarrays to compare CRC tissues and normal adjacent mucosa, identifying 35 differentially expressed miRNAs [88]. Next, they developed a 6-miRNA-based classifier and evaluated its prognostic and predictive values in three independent sets of patients [88]. Based on this classifier, patients were classified according to their risk of disease progression. Five-year disease-free survival was higher in low risk patients compare with those at high risk in either set of patients analyzed. Interestingly, patients with high risk of disease progression exhibited a better response to 5-FU based adjuvant chemotherapy [88]. To and colleagues examined miR-519c expression in CRC patients receiving adjuvant chemotherapy, and its association with ATP Binding Cassette Subfamily G Member 2 (ABCG2) expression [89]. Notably, miR-519c levels were positively correlated with ABCG2 expression, and the most of CRC samples from non-responders exhibited miR-519c downregulation [89]. Diaz 
and colleagues compared expression levels of several miRNAs (i.e., including miR-200a, miR-200b, miR-200c, miR-141, and miR-429) between tumor and adjacent normal tissues in CRC patients receiving 5-FU or XELOX treatment [90]. They demonstrated that upregulation of miR-200a, miR-200c and miR-429 was associated with better survival. Among patients receiving 5-FU based adjuvant therapy, upregulation of miR-200a, miR-200c, miR-141, or miR-429 was positively associated with overall and disease-free survival [90]. Li and colleagues compared miR-215 expression between CRC patients with or without recurrence within 3 years after surgery [91]. Patients with recurrence exhibited lower miR-215 expression level than those without recurrence. Moreover, the Authors observed that miR-215 downregulation was associated with worse response to 5-FU adjuvant therapy [91]. Dou and colleagues specifically aimed to evaluate genes and miRNAs that allowed them to identify CRC patients who could benefit from adjuvant chemotherapy [92]. They revealed 17 differentially expressed miRNAs between responders and non-responders. These results, along with those from gene expression analysis, allowed to identify 3 genes (i.e., Aquaporin-9, Special AT-Rich Sequence-Binding Protein 2, Wnt Inhibitory Factor 1; AQP9, SATB2, and WIF1, respectively) that were downregulated by the differentially expressed miRNAs [92]. Differently from above studies, Conev and colleagues evaluated whether expression of four miRNAs (i.e., miR-17, miR-21, miR-29a, and miR-92) in serum samples might predict the risk of recurrence in colon cancer patients receiving adjuvant chemotherapy [93]. They demonstrated that miR-17, miR-21 and miR-92 were upregulated in patients with recurrence, with AUC of $0.844,0.948$, and 0.935 , respectively. Notably, a test based on the four miRNAs allowed to discriminate patients at higher risk of recurrence, with a sensitivity of $83.3 \%$ and a specificity of 85.7\% [93]. In line with this evidence, Liu and colleagues examined the potential of serum exosomal miRNAs to predict the risk of recurrence and the response to adjuvant chemotherapy in colon cancer patients [94]. Using RNA sequencing, they identified 145 differentially expressed miRNAs between patients with or without recurrence. Particularly, downregulation of miR-4772-3p was associated with an increased risk of recurrence, with an AUC of 0.72. This evidence was confirmed in patients receiving adjuvant therapy [94]. 
Table 7. MiRNA signatures in patients receiving adjuvant chemotherapy.

\begin{tabular}{|c|c|c|c|c|c|c|c|c|}
\hline $\begin{array}{l}\text { First Author } \\
\text { and Year }\end{array}$ & Tumor & $\begin{array}{l}\text { Overall } \\
\text { Population } \\
\text { (Treated } \\
\text { Patients) }\end{array}$ & Treatment & Samples & Markers & Methods & Response to Treatment & Other Findings \\
\hline $\begin{array}{l}\text { Schetter, A.J., } \\
2008 \text { [83] }\end{array}$ & Colon cancer & $197(72)$ & 5-FU & $\begin{array}{l}\text { Tumor and } \\
\text { normal tissues }\end{array}$ & $\begin{array}{l}\text { miR-20a, } \\
\text { miR-203, } \\
\text { miR-21, } \\
\text { miR-106a, } \\
\text { miR-181b }\end{array}$ & $\begin{array}{l}\text { Microarray and } \\
\text { Real-time PCR }\end{array}$ & $\begin{array}{l}\text { miR-20a, miR-21, miR-106a, } \\
\text { miR-181b, and miR-203 were } \\
\text { enriched in tumor tissues. } \\
\text { MiR-21 upregulation was } \\
\text { associated with poor survival } \\
\text { and poor therapeutic response in } \\
\text { both cohorts }\end{array}$ & $\begin{array}{l}37 \text { miRNAs were differentially expressed } \\
\text { between tumor and normal tissues }\end{array}$ \\
\hline $\begin{array}{l}\text { Oue, N., } 2014 \\
{[84]}\end{array}$ & Colon cancer & $301(84)$ & 5-FU & Tumor tissues & miR-21 & Real-time PCR & $\begin{array}{c}\text { Patients with miR-21 } \\
\text { upregulation did not benefit } \\
\text { from the adjuvant chemotherapy }\end{array}$ & $\begin{array}{l}\text { Upregulation of miR-21 was associated } \\
\text { with poor survival independent of } \\
\text { clinicopathological features }\end{array}$ \\
\hline $\begin{array}{l}\text { Coebergh van } \\
\text { den Braak, } \\
\text { R.R.J., } 2018 \text { [85] }\end{array}$ & Colon cancer & $232(77)$ & NA & $\begin{array}{l}\text { Tumor and } \\
\text { normal tissues }\end{array}$ & $\begin{array}{l}\text { let-7i, miR-10b } \\
\text { and miR-30b }\end{array}$ & Real-time PCR & $\begin{array}{l}\text { The 2-miRNA signature (let-7i } \\
\text { and miR-10b) had no prognostic } \\
\text { value in stage III patients } \\
\text { receiving adjuvant therapy }\end{array}$ & $\begin{array}{l}\text { The 2-miRNA signature (let-7i and } \\
\text { miR-10b) predicted hepatic recurrence in } \\
\text { stage I-II patients, while the } \\
\text { combination with miR-30b also } \\
\text { predicted distant metastasis }\end{array}$ \\
\hline Ma, Y., 2011 [86] & CRC & 424 (NA) & NA & $\begin{array}{l}\text { Tumor and } \\
\text { normal tissues }\end{array}$ & miR-150 & $\begin{array}{l}\text { Microarray and } \\
\text { Real-time PCR }\end{array}$ & $\begin{array}{l}\text { Low miR-150 expression levels } \\
\text { were associated with reduced } \\
\text { overall survival and worse } \\
\text { response to treatment }\end{array}$ & $\begin{array}{l}\text { MiR-150 was downregulated in tumors } \\
\text { compared with adjacent normal tissues }\end{array}$ \\
\hline $\begin{array}{l}\text { Perez-Carbonell, } \\
\text { L., } 2015 \text { [87] }\end{array}$ & CRC & $\begin{array}{c}\text { Discovery } \\
\text { cohort: } 100 \text { (NA) } \\
\text { Validation } \\
\text { cohort: } 237(167)\end{array}$ & $\begin{array}{l}\text { FOLFOX, } \\
5 \text {-FU, or } \\
5 \text {-FU and } \\
\text { oxaliplatin }\end{array}$ & Tumor tissues & miR-320e & $\begin{array}{l}\text { Microarray and } \\
\text { Real-time PCR }\end{array}$ & Not examined & $\begin{array}{l}\text { MiR-320e was upregulated in patients } \\
\text { with recurrence compared with those } \\
\text { without recurrence. MiR-320e } \\
\text { upregulation was associated with poor } \\
\text { overall and disease-free survival and } \\
\text { overall survival }\end{array}$ \\
\hline $\begin{array}{l}\text { Zhang, J.X., } \\
2013 \text { [88] }\end{array}$ & CRC & $\begin{array}{l}\text { Training set: } 138 \\
\text { (NA) Internal } \\
\text { set: } 137 \text { (NA) } \\
\text { Validation set: } \\
360 \text { (NA) }\end{array}$ & 5-FU & Tumor tissues & $\begin{array}{l}\text { miR-20a-5p, } \\
\text { miR-21-5p, } \\
\text { miR-103a-3p, } \\
\text { miR-106a-5p, } \\
\text { miR-143-5p, and } \\
\text { miR-215 }\end{array}$ & $\begin{array}{l}\text { Microarray and } \\
\text { Real-time PCR }\end{array}$ & $\begin{array}{c}\text { Based on a 6-miRNA-based } \\
\text { classifier, patients with high risk } \\
\text { of disease progression exhibited } \\
\text { a better response to 5-FU based } \\
\text { adjuvant chemotherapy }\end{array}$ & $\begin{array}{l}35 \text { miRNAs were differentially } \\
\text { expressed between tumor and normal } \\
\text { tissues. Based on a 6-miRNA-based } \\
\text { classifier, patients were classified } \\
\text { according to their risk of disease } \\
\text { progression. Five-year disease-free } \\
\text { survival was higher in low risk patients } \\
\text { compare with those at high risk }\end{array}$ \\
\hline
\end{tabular}


Table 7. Cont.

\begin{tabular}{|c|c|c|c|c|c|c|c|c|}
\hline $\begin{array}{l}\text { First Author } \\
\text { and Year }\end{array}$ & Tumor & $\begin{array}{c}\text { Overall } \\
\text { Population } \\
\text { (Treated } \\
\text { Patients) }\end{array}$ & Treatment & Samples & Markers & Methods & Response to Treatment & Other Findings \\
\hline $\begin{array}{l}\text { To, K.K., } 2015 \\
{[89]}\end{array}$ & Colon cancer & $26(26)$ & NA & Tumor tissues & miR-519c & Real-time PCR & $\begin{array}{l}\text { Most of CRC samples from } \\
\text { non-responders exhibited } \\
\text { miR-519c downregulation }\end{array}$ & $\begin{array}{l}\text { MiR-519c levels were positively } \\
\text { correlated with ABCG2 expression }\end{array}$ \\
\hline $\begin{array}{l}\text { Diaz, T., } 2014 \\
{[90]}\end{array}$ & CRC & $127(56 / 24)$ & $\begin{array}{l}\text { 5-FU or } \\
\text { XELOX }\end{array}$ & $\begin{array}{l}\text { Tumor and } \\
\text { normal tissues }\end{array}$ & $\begin{array}{l}\text { miR-200 family, } \\
\text { miR-141, } \\
\text { miR-429 }\end{array}$ & Real-time PCR & $\begin{array}{l}\text { Among patients receiving } 5 \text {-FU } \\
\text { based adjuvant therapy, } \\
\text { upregulation of miR-200a, } \\
\text { miR-200c, miR-141, or miR-429 } \\
\text { was positively associated with } \\
\text { overall and disease-free survival }\end{array}$ & $\begin{array}{l}\text { Upregulation of miR-200a, miR-200c and } \\
\text { miR-429 was associated with better } \\
\text { survival }\end{array}$ \\
\hline Li, S., 2013 [91] & CRC & $125(91)$ & 5-FU & Tumor tissues & miR-215 & Real-time PCR & $\begin{array}{l}\text { MiR-215 downregulation was } \\
\text { associated with worse response } \\
\text { to 5-FU adjuvant therapy }\end{array}$ & $\begin{array}{l}\text { Patients with recurrence exhibited lower } \\
\text { miR-215 expression level than those } \\
\text { without recurrence }\end{array}$ \\
\hline Dou, R., 2013 & CRC & $35(35)$ & FOLFOX6 & Tumor tissues & 17 miRNAs & $\begin{array}{l}\text { Microarray and } \\
\text { Real-time PCR }\end{array}$ & $\begin{array}{l}17 \text { miRNAs were differentially } \\
\text { expressed between responders } \\
\text { and non-responders }\end{array}$ & $\begin{array}{c}\text { Three genes (AQP9, SATB2, and WIF1) } \\
\text { were downregulated by the } \\
\text { differentially expressed miRNAs }\end{array}$ \\
\hline $\begin{array}{l}\text { Conev, N.V., } \\
2015 \text { [93] }\end{array}$ & Colon cancer & $37(37)$ & 5-FU & Serum & $\begin{array}{l}\text { miR-17, miR-21, } \\
\text { miR-29a, and } \\
\text { miR-92 }\end{array}$ & Real-time PCR & Not examined & $\begin{array}{l}\text { MiR-17, miR-21 and miR-92 were } \\
\text { upregulated in patients with recurrence }\end{array}$ \\
\hline Liu, C., 2016 [94] & Colon cancer & $84(66)$ & FOLFOX & Serum & miR-4772-3p & $\begin{array}{l}\text { RNA-seq and } \\
\text { Real-time PCR }\end{array}$ & $\begin{array}{l}\text { Downregulation of miR-4772-3p } \\
\text { was associated with an increased } \\
\text { risk of recurrence. This evidence } \\
\text { was confirmed in patients } \\
\text { receiving adjuvant therapy }\end{array}$ & $\begin{array}{l}145 \text { miRNAs were differentially } \\
\text { expressed between patients with or } \\
\text { without recurrence }\end{array}$ \\
\hline
\end{tabular}

Factor 1. 


\subsection{MicroRNA in Patients Receiving Neoadjuvant Therapy}

With respect to rectal cancer patients receiving neoadjuvant chemoradiation, other research groups investigated the predictive and prognostic values of several miRNAs, and their main findings are summarized in Table 8. In 2012, Gaedcke and colleagues applied a miRNA microarray to compare miRNA expression between tumor tissues and adjacent normal mucosa in rectal cancer patients receiving neoadjuvant chemoradiation [95]. A preliminary analysis identified a set of miRNA (i.e., miR-492, miR-542-5p, miR-584, miR-483-5p, miR-144, miR-2110, miR-652, miR-375, miR-147b, miR-148a, miR-190, miR-26a/b, and miR-338-3p) that were differently expressed between rectal and colon cancer tissues [95]. In an independent cohort, the Authors demonstrated that miR-135b expression correlated with tumor regression grade, disease-free survival and cancer-specific survival [95]. In the same years, Drebber and colleagues examined expression of miR-21, -143 and -145 in rectal cancer receiving neoadjuvant chemoradiotherapy: among these miRNAs, miR-21 was upregulated in tumor tissue than in adjacent normal mucosa [96]. With respect to changes induced by neoadjuvant chemoradiation, miR-21 was downregulated while miR-143 and miR-145 were upregulated in post-treatment tissues compared with pre-treatment tissues. In addition, post-treatment miR-145 downregulation seemed to be associated with worse response to neoadjuvant therapy [96]. In 2012, independent research groups begun to investigate miRNA-signatures that allowed to predict response to neoadjuvant chemoradiation by comparing responders with non-responders. Svoboda and colleagues applied a miRNA microarray to rectal cancer patients receiving neoadjuvant chemoradiation classified as responders or non-responders [97]. They identified eight differentially expressed miRNAs, as such miR-215, miR-190b and miR-29b-2 were upregulated in non-responders, while let-7e, miR-196b, miR-450a, miR-450b-5p and miR-99a were upregulated in responders. Interestingly, this 8-miRNA signature allowed to correctly classify $90 \%$ of non-responders [97]. Kheirelseid and colleagues performed a microarray analysis on pre-treatment tissues of rectal cancer patients receiving neoadjuvant chemoradiation [98]. They identified a 3-miRNA signature (i.e., miR-16, miR-590-5p and miR-153) that predicted incomplete response to neoadjuvant therapy [98]. They also proposed a 2-miRNA signature (i.e., miR-519c-3p and miR-561) that predicted poor response to neoadjuvant therapy with an accuracy of $100 \%$ [98]. Della Vittoria Scarpati and colleagues used the same approach on rectal cancer patients receiving neoadjuvant therapy classified by their tumor regression grade [99]. Accordingly, they first identified 14 differentially expressed miRNAs in patients with complete response [99]. Next, they validated 11 upregulated (miR-1183, miR-483-5p, miR-622, miR-125a-3p, miR-1224-5p, miR-188-5p, miR-1471, miR-671-5p, miR-1909, miR-630, miR-765) and two downregulated (miR-1274b, miR-720) miRNAs in the same patients. Notably, miR-622 and miR-630 showed $100 \%$ sensitivity and specificity in discriminating patients with complete response [99]. In line with this finding, Campayo and colleagues identified eight miRNAs (i.e., let-7b, let-7e, miR-21, miR-99b, miR-183, miR-328, miR-375 and miR-483-5p) that were differentially expressed across different tumor regression grades [100]. In a validation set, they observed that miR-21, miR-99b and miR-375 were associated with disease-free and overall survival [100]. Accordingly, the Authors concluded that the combination of miR-21, miR-99b and miR-375 allowed to discriminate patients with complete response to neoadjuvant therapy [100]. In 2014, Lopes-Ramos and colleagues profiled miRNAs using RNA-sequencing in pre-treatment rectal cancer tissues from patients receiving neoadjuvant chemoradiation [101]. They first identified four differentially expressed miRNAs between complete and incomplete responders in a training set [101]. Next, they confirmed that miR-21-5p was upregulated in complete responders of a validation set. Interestingly, miR-21-5p expression level allowed the prediction of complete response to neoadjuvant therapy with a sensitivity of $78 \%$ and a specificity of $86 \%$ [101]. In 2016, Caramés and colleagues measured miR-31 expression level in rectal cancer tissues from patients receiving neoadjuvant chemoradiation, using real-time PCR [102]. They observed higher miR-31 level in patients with poor response than in those with complete response. Accordingly, miR-31 upregulation was associated with poor pathological response and worse overall survival [102]. Similarly, D'Angelo and colleagues demonstrated that miR-194 was overexpressed in patients who responded to neoadjuvant chemoradiation [103]. More 
recently, Du and colleagues identified 41 differentially expressed miRNAs between complete and incomplete responders to neoadjuvant therapy [104]. Among these miRNAs, miR-548c-5p/miR-548d-5p and $\mathrm{miR}-663 \mathrm{a}$ regulated genes associate with rectal cancer, thereby modulating the complete response to neoadjuvant chemoradiation [104]. Luo and colleagues measured the expression level of miR-519b-3p in patients receiving neoadjuvant therapy, demonstrating a positive correlation with response to treatment [105]. Interestingly, functional analysis suggested that miR-519b-3p was directly involved in response to neoadjuvant chemoradiation in an ARID4B-dependent way [105]. In 2016, Yu and colleagues used a microarray to examine miRNA profiles in pre-treatment tissue and serum samples from rectal cancer patients receiving neoadjuvant chemoradiation [106]. In a validation set, miR-345 upregulation was associated with a worse response to treatment either in tissue or serum. Accordingly, miR-345 downregulation in serum was associated with better recurrence-free survival [106]. In line with this evidence and results from above studies, Menéndez and colleagues evaluated serum expression level of miR-21—one of the most investigated miRNAs in this field of research - in rectal cancer patients [107]. Interestingly, serum miR-21 downregulation was associated with high risk of recurrence and death. Indeed, a Cox regression analysis demonstrated that miR-21 expression was an independent predictor of overall survival [107]. Recently, Hiyoshi and colleagues analyzed 18 serum miRNAs in rectal patients receiving neoadjuvant chemoradiation, using real-time PCR [108]. Among these miRNAs, miR-143 was associated with response to treatment, with higher expression levels in responders than in non-responders. A multivariate analysis confirmed serum miR-143 expression as an independent predictor of pathological response [108]. 
Table 8. MiRNA signatures in rectal cancer patients receiving neoadjuvant chemoradiation.

\begin{tabular}{|c|c|c|c|c|c|c|c|c|}
\hline $\begin{array}{l}\text { First Author } \\
\text { and Year }\end{array}$ & Tumor & $\begin{array}{c}\text { Overall } \\
\text { Population } \\
\text { (Treated } \\
\text { Patients) }\end{array}$ & Treatment & Samples & Markers & Methods & Response to Treatment & Other Findings \\
\hline $\begin{array}{l}\text { Gaedcke, J., } \\
2012 \text { [95] }\end{array}$ & Rectal cancer & $57(57)$ & Chemoradiation & Tumor tissues & $\operatorname{miR}-135 b$ & Microarray & Not examined & $\begin{array}{c}\text { MiR-492, miR-542-5p, miR-584, } \\
\text { miR-483-5p, miR-144, } \\
\text { miR-2110, miR-652, miR-375, } \\
\text { miR-147b, miR-148a, miR-190, } \\
\text { miR-26a/b, and miR-338-3p } \\
\text { were differentially expressed } \\
\text { between rectal and colon } \\
\text { cancer tissues. MiR-135b } \\
\text { expression correlated with } \\
\text { tumor regression grade, } \\
\text { disease-free survival and } \\
\text { cancer-specific survival }\end{array}$ \\
\hline $\begin{array}{l}\text { Drebber, U., } \\
2011 \text { [96] }\end{array}$ & Rectal cancer & $40(40)$ & Chemoradiation & Tumor tissues & $\begin{array}{l}\text { miR-21, miR-143 } \\
\text { and miR-145 }\end{array}$ & Real-time PCR & $\begin{array}{c}\text { Compared to pre-treatment } \\
\text { tissues, miR-21 was } \\
\text { downregulated while miR-143 } \\
\text { and miR-145 were upregulated } \\
\text { in post-treatment tissues. } \\
\text { MiR-145 downregulation was } \\
\text { associated with worse response } \\
\text { to neoadjuvant therapy }\end{array}$ & $\begin{array}{l}\text { MiR-21 was upregulated in } \\
\text { tumor tissue than in adjacent } \\
\text { normal mucosa }\end{array}$ \\
\hline $\begin{array}{l}\text { Svoboda, M., } \\
2012 \text { [97] }\end{array}$ & Rectal cancer & $20(20)$ & Chemoradiation & Tumor tissues & $\begin{array}{c}\text { miR-215, } \\
\text { miR-190b, } \\
\text { miR-29b-2, } \\
\text { let-7e, miR-196b, } \\
\text { miR-450a, } \\
\text { miR-450b-5p } \\
\text { and miR-99a }\end{array}$ & $\begin{array}{l}\text { Microarray and } \\
\text { Real-time PCR }\end{array}$ & $\begin{array}{c}\text { Eight miRNAs were } \\
\text { differentially expressed } \\
\text { between responders and } \\
\text { non-responders. MiR-215, } \\
\text { miR-190b and miR-29b-2 were } \\
\text { upregulated in non-responders, } \\
\text { while let-7e, miR-196b, } \\
\text { miR-450a, miR-450b-5p and } \\
\text { miR-99a were upregulated in } \\
\text { responders. This 8-miRNA } \\
\text { signature allowed to correctly } \\
\text { classify } 90 \% \text { of non-responders }\end{array}$ & NA \\
\hline
\end{tabular}


Table 8. Cont.

\begin{tabular}{|c|c|c|c|c|c|c|c|c|}
\hline $\begin{array}{l}\text { First Author } \\
\text { and Year }\end{array}$ & Tumor & $\begin{array}{l}\text { Overall } \\
\text { Population } \\
\text { (Treated } \\
\text { Patients) }\end{array}$ & Treatment & Samples & Markers & Methods & Response to Treatment & Other Findings \\
\hline $\begin{array}{l}\text { Kheirelseid, } \\
\text { E.A., } 2012 \text { [98] }\end{array}$ & Rectal cancer & $12(12)$ & Chemoradiation & Tumor tissues & $\begin{array}{l}\text { miR-16, } \\
\text { miR-590-5p, } \\
\text { miR-153, } \\
\text { miR-519c-3p, } \\
\text { and miR-561 }\end{array}$ & $\begin{array}{l}\text { Microarray and } \\
\text { Real-time PCR }\end{array}$ & $\begin{array}{l}\text { A 3-miRNA signature (miR-16, } \\
\text { miR-590-5p and miR-153) } \\
\text { predicted incomplete response } \\
\text { to neoadjuvant therapy. A } \\
\text { 2-miRNA signature } \\
\text { (miR-519c-3p and miR-561) } \\
\text { predicted poor response to } \\
\text { neoadjuvant therapy with an } \\
\text { accuracy of } 100 \% \\
\end{array}$ & NA \\
\hline $\begin{array}{l}\text { Della Vittoria } \\
\text { Scarpati, G., } \\
2012 \text { [99] }\end{array}$ & Rectal cancer & $38(38)$ & Chemoradiation & Tumor tissues & $\begin{array}{c}\text { miR-1183, } \\
\text { miR-483-5p, } \\
\text { miR-622, } \\
\text { miR-125a-3p, } \\
\text { miR-1224-5p, } \\
\text { miR-188-5p, } \\
\text { miR-1471, } \\
\text { miR-671-5p, } \\
\text { miR-1909, } \\
\text { miR-630, } \\
\text { miR-765, } \\
\text { miR-1274b, } \\
\text { miR-720 }\end{array}$ & $\begin{array}{l}\text { Microarray and } \\
\text { Real-time PCR }\end{array}$ & $\begin{array}{c}14 \text { miRNAs were differentially } \\
\text { expressed in patients with } \\
\text { complete response. } 11 \text { miRNAs } \\
\text { were upregulated (miR-1183, } \\
\text { miR-483-5p, miR-622, } \\
\text { miR-125a-3p, miR-1224-5p, } \\
\text { miR-188-5p, miR-1471, } \\
\text { miR-671-5p, miR-1909, } \\
\text { miR-630, miR-765), while 2 } \\
\text { miRNAs were downregulated } \\
\text { (miR-1274b, miR-720). MiR-622 } \\
\text { and miR-630 showed } 100 \% \\
\text { sensitivity and specificity in } \\
\text { discriminating patients with } \\
\text { complete response }\end{array}$ & NA \\
\hline $\begin{array}{l}\text { Campayo, M., } \\
2018 \text { [100] }\end{array}$ & Rectal cancer & $96(96)$ & Chemoradiation & Tumor tissues & $\begin{array}{l}377 \text { miRNAs } \\
\text { including } \\
\text { miR-21, } \\
\text { miR-99b and } \\
\text { miR-375 }\end{array}$ & $\begin{array}{c}\text { Microarray and } \\
\text { Real-time PCR }\end{array}$ & $\begin{array}{c}8 \text { miRNAs (let-7b, let-7e, } \\
\text { miR-21, miR-99b, miR-183, } \\
\text { miR-328, miR-375 and } \\
\text { miR-483-5p) were differentially } \\
\text { expressed across different } \\
\text { tumor regression grades. The } \\
\text { combination of miR-21, } \\
\text { miR-99b and miR-375 allowed } \\
\text { to discriminate patients with } \\
\text { complete response to } \\
\text { neoadjuvant therapy }\end{array}$ & $\begin{array}{l}\text { MiR-21, miR-99b and miR-375 } \\
\text { were associated with } \\
\text { disease-free and overall } \\
\text { survival. }\end{array}$ \\
\hline
\end{tabular}


Table 8. Cont.

\begin{tabular}{|c|c|c|c|c|c|c|c|c|}
\hline $\begin{array}{l}\text { First Author } \\
\text { and Year }\end{array}$ & Tumor & $\begin{array}{l}\text { Overall } \\
\text { Population } \\
\text { (Treated } \\
\text { Patients) }\end{array}$ & Treatment & Samples & Markers & Methods & Response to Treatment & Other Findings \\
\hline $\begin{array}{c}\text { Lopes-Ramos, } \\
\text { C.M., } 2014 \text { [101] }\end{array}$ & Rectal cancer & $\begin{array}{c}\text { Training cohort: } \\
27(27) \\
\text { Validation } \\
\text { cohort: } 16(16)\end{array}$ & Chemoradiation & Tumor tissues & miR-21-5p & $\begin{array}{l}\text { RNA-seq and } \\
\text { Real-time PCR }\end{array}$ & $\begin{array}{l}\text { In the training set, four } \\
\text { miRNAs were differentially } \\
\text { expressed between complete } \\
\text { and incomplete responders. In } \\
\text { the validation set, miR-21-5p } \\
\text { was upregulated in complete } \\
\text { responders. MiR-21-5p } \\
\text { expression level allowed the } \\
\text { prediction of complete } \\
\text { response to neoadjuvant } \\
\text { therapy with a sensitivity of } \\
78 \% \text { and a specificity of } 86 \%\end{array}$ & NA \\
\hline $\begin{array}{l}\text { Caramés, C., } \\
2016 \text { [102] }\end{array}$ & Rectal cancer & 78 (78) & Chemoradiation & Tumor tissues & mir-31 & Real-time PCR & $\begin{array}{l}\text { MiR-31 expression level were } \\
\text { higher in patients with } \\
\text { complete response than in } \\
\text { those with poor response }\end{array}$ & $\begin{array}{l}\text { MiR-31 upregulation was } \\
\text { associated with poor } \\
\text { pathological response and } \\
\text { worse overall survival }\end{array}$ \\
\hline $\begin{array}{l}\text { D'Angelo, E., } \\
2017 \text { [103] }\end{array}$ & Rectal cancer & $38(38)$ & Chemoradiation & Tumor tissues & miR-194 & Real-time PCR & $\begin{array}{l}\text { MiR-194 was overexpressed in } \\
\text { patients who responded to } \\
\text { neoadjuvant chemoradiation }\end{array}$ & NA \\
\hline $\begin{array}{c}\text { Du, B., } 2018 \\
\text { [104] }\end{array}$ & Rectal cancer & $38(38)$ & Chemoradiation & Tumor tissues & 41 miRNAs & Microarray & $\begin{array}{l}41 \text { miRNAs were differentially } \\
\text { expressed between complete } \\
\text { and incomplete responders to } \\
\text { neoadjuvant therapy. } \\
\text { MiR-548c-5p/miR-548d-5p and } \\
\text { miR-663a regulated genes } \\
\text { associate with rectal cancer, } \\
\text { thereby modulating the } \\
\text { complete response to } \\
\text { neoadjuvant chemoradiation }\end{array}$ & NA \\
\hline
\end{tabular}


Table 8. Cont

\begin{tabular}{|c|c|c|c|c|c|c|c|c|}
\hline $\begin{array}{l}\text { First Author } \\
\text { and Year }\end{array}$ & Tumor & $\begin{array}{l}\text { Overall } \\
\text { Population } \\
\text { (Treated } \\
\text { Patients) }\end{array}$ & Treatment & Samples & Markers & Methods & Response to Treatment & Other Findings \\
\hline $\begin{array}{l}\text { Luo, J., } 2018 \\
\text { [105] }\end{array}$ & Rectal cancer & $55(55)$ & Chemoradiation & Tumor tissues & miR-519b-3p & Real-time PCR & $\begin{array}{c}\text { In patients receiving } \\
\text { neoadjuvant therapy, } \\
\text { miR-519b-3p expression was } \\
\text { positively correlated with } \\
\text { response to treatment. A } \\
\text { functional analysis suggested } \\
\text { that miR-519b-3p was directly } \\
\text { involved in response to } \\
\text { neoadjuvant chemoradiation in } \\
\text { an ARID4B-dependent way }\end{array}$ & NA \\
\hline Yu, J., 2016 [106] & Rectal cancer & 149 (149) & Chemoradiation & $\begin{array}{l}\text { Tumor tissues } \\
\text { and serum }\end{array}$ & miR-345 & $\begin{array}{l}\text { Microarray and } \\
\text { Real-time PCR }\end{array}$ & $\begin{array}{l}\text { MiR-345 upregulation was } \\
\text { associated with a worse } \\
\text { response to treatment either in } \\
\text { tissue or serum }\end{array}$ & $\begin{array}{l}\text { MiR-345 downregulation in } \\
\text { serum was associated with } \\
\text { better recurrence-free survival }\end{array}$ \\
\hline $\begin{array}{l}\text { Menéndez, P., } \\
2013 \text { [107] }\end{array}$ & Rectal cancer & $28(28)$ & Chemoradiation & Serum & $\mathrm{miR}-21$ & Real-time PCR & Not examined & $\begin{array}{c}\text { Serum miR-21 downregulation } \\
\text { was associated with high risk } \\
\text { of recurrence and death. } \\
\text { MiR-21 expression was an } \\
\text { independent predictor of } \\
\text { overall survival }\end{array}$ \\
\hline $\begin{array}{c}\text { Hiyoshi, Y., } 2017 \\
\text { [108] }\end{array}$ & Rectal cancer & $94(94)$ & Chemoradiation & Serum & $\begin{array}{c}\text { let-7b, miR-15b, } \\
\text { miR-20a, } \\
\text { miR-21, } \\
\text { miR-29a, } \\
\text { miR-92a, } \\
\text { miR-122, } \\
\text { miR-125b, } \\
\text { miR-141, } \\
\text { miR-143, } \\
\text { miR-145, } \\
\text { miR-155, } \\
\text { miR-200c, } \\
\text { miR-221, } \\
\text { miR-345, } \\
\text { miR-423, } \\
\text { miR-425, } \\
\text { miR-1246 }\end{array}$ & Real-time PCR & $\begin{array}{l}\text { Serum miR-143 expression was } \\
\text { higher in responders than in } \\
\text { non-responders. Serum } \\
\text { miR-143 expression was an } \\
\text { independent predictor of } \\
\text { pathological response }\end{array}$ & NA \\
\hline
\end{tabular}




\section{Discussion}

Over the past decades, CRC has become one of the most common cancers with an associated mortality that remains high in spite of substantial advances in treatment and patient management [1]. Moreover, each treatment is associated with specific adverse effects and complications [23]. For instance, treatment with oxaliplatin or irinotecan is often associated with adverse effects, such as neutropenia and diarrhea, while chemotherapy with 5-fluorouracil is usually well tolerated [23]. Moreover, strategies aiming to improve the response to neoadjuvant therapy by intensifying the chemoradiotherapy regimen (e.g., the combination of 5-FU and oxaliplatin with radiotherapy) did not exhibit clear survival benefit, and even increased toxicity with persisting chronic complications in many patients [23]. Thus, despite strides in the application of adjuvant and/or neoadjuvant therapies, there is currently an unresolved need for distinguishing patients who might respond to treatment from those who do not. Although several molecular biomarkers have been proposed for predicting the response to treatment, more efforts should be made to tailor therapies for patients with specific molecular features [23].

In this scenario, our study provides the first systematic review of epidemiological studies investigating the predictive and prognostic value of epigenetic biomarkers in CRC patients receiving neoadjuvant and/or adjuvant therapies. We summarized that gene-specific methylation has been associated with risk of recurrence, response to treatment, and survival in patients receiving either adjuvant or neoadjuvant therapy. For instance, demethylation of MGMT promoter in tumor tissue seemed to be associated with higher risk of recurrence in general, and specifically in patients who received adjuvant chemotherapy. By contrast, those with MGMT hypermethylation had a reduced risk of recurrence [32]. A plausible explanation is that the repression of MGMT expression by promoter methylation might cause a decrease in its DNA repair activity, hereby enhancing the effectiveness of chemotherapy [32]. In line with this evidence, MGMT hypermethylation of cell-free DNA from serum was associated with improved response to treatment and higher regression in rectal cancer patients who received 5-FU-based neoadjuvant chemoradiation [78]. However, these findings need to be confirmed by further research, since other groups found no significant association between MGMT methylation and prognosis in CRC patients [33]. Another gene that has been associated with CRC prognosis and response to adjuvant therapy was MLH1. Particularly, patients receiving 5-FU-based adjuvant therapy with MLH1 hypermethylation and reduced expression levels had a significantly longer disease-free survival than their counterpart [35]. Indeed, methylation of MLH1 promoter can cause a defect in the mismatch repair system along with germline mutations in mismatch repair genes [36]. Based on these findings and also those reported by other studies, several panels of methylation markers (i.e., CIMP) have been proposed for predicting prognosis in CRC patients. In general, CIMP+ status seemed to be associated with worse disease-free and overall survival in either CRC or colon cancer patients; however, more benefits from the adjuvant therapy were reported in CIMP+ than in CIMPpatients. In contrast, studies investigating CIMP panels in rectal cancer patients receiving neoadjuvant therapy demonstrated no association with response to treatment. Toyota and colleagues were the first reporting the classification of CIMP status about twenty years ago [109], but there is as yet no consensus on the definitive panel for classifying it. Indeed, the comparison of several CIMP panels found significant differences in CIMP positivity determined by different panels [110]. This variability should be taken into account when comparing findings from different studies and before proposing a certain panel for risk stratification.

With respect to miRNAs, independent studies conducted on Caucasian and Asian populations demonstrated the relationship between miR-21 upregulation in tumor tissue and poor survival of CRC patients receiving adjuvant therapy $[83,84]$. Instead, patients with miR-21 upregulation did not benefit from the adjuvant chemotherapy [84]. In rectal cancer patients who received neoadjuvant chemoradiotherapy, the analysis of three different miRNAs revealed that miR-21 was upregulated in tumor tissue but not in the adjacent normal mucosa [96]. However, patients with higher miR-21 levels exhibited better disease-free and overall survival than those with lower miR-21 expression [100]. In 
addition, the combination of miR-21 with miR-99b and miR-375 (i.e., the sum of their expression levels) allowed to discriminate patients with complete response to neoadjuvant therapy [100]. Consistently, RNA-sequencing of rectal cancer tissues from patients receiving neoadjuvant chemoradiation demonstrated that miR-21-5p —one of the mature sequences of miR-21—was upregulated in complete responders [101]. Indeed, the evaluation of its expression level allowed the prediction of complete response to neoadjuvant therapy with a sensitivity of $78 \%$ and a specificity of $86 \%$ [101]. In line with this evidence, expression level of miR-21 was further investigated in serum samples from rectal cancer patients [107]. This study demonstrated that downregulation of miR-21 was associated with higher risk of recurrence and death, as confirmed by a Cox regression analysis [107]. Beyond miR-21, other miRNA-signatures in the serum have been proposed to predict overall survival, risk of recurrence and response to treatment with high sensitivity and specificity. However, further large-size prospective studies are required to confirm the reliability and the robustness of these findings.

In general, studies included in our systematic review showed high heterogeneity in terms of disease classification, methods for determining methylation, and tumor response evaluation. Compared with other tumors, several molecular features (e.g., DNA mutation, epigenetic signatures, and oncogenic pathway action) make CRC a heterogeneous disease with high intra-tumor heterogeneity [111]. In addition, we found significant heterogeneity in treatment schedules, which might lead to different response to treatment. The high heterogeneity between and within tumors limits the sensitivity and specificity of single biomarkers to predict response to treatment. Thus, in our opinion, considerable efforts are required to elucidate the efficacy of these markers for classifying CRC patients according to their response to treatment, and to combine these epigenetic signatures into wider panels of molecular and clinical markers. Moreover, our systematic review pointed out the lack of evidence on the effects of histone modifications on the response to adjuvant or neoadjuvant therapies. Since histone modifications have been associated with aberrant gene expression in cancer development and progression, their implication as potential biomarkers for response to therapies should be investigated in the future.

In conclusion, our systematic review identified several epigenetic markers in CRC patients who received surgery with adjuvant or neoadjuvant therapy. However, none of them currently has the robustness to be translated into the clinical setting. While most studies generally focused on only one type of biomarker, an integrated approach of gene expression profiles, DNA methylation, and miRNAs might allow us to develop more accurate biomarker panels that can predict response to adjuvant or neoadjuvant therapy. With this in mind, more efforts and further large-size prospective studies and/or trials should be encouraged to develop epigenetic biomarker panels for personalized prevention and medicine in CRC cancer.

Supplementary Materials: Supplementary materials can be found at http://www.mdpi.com/1422-0067/20/15/ $3842 / s 1$.

Author Contributions: Conceptualization, M.B., A.M., G.L.D., G.B. and A.A.; methodology, M.B. and A.M.; investigation, M.B. and A.M.; resources, G.L.D. and A.A.; writing—original draft preparation, M.B. and A.M.; writing-review and editing, all the Authors; supervision, A.A.

Funding: This research was funded by the Department of Medical and Surgical Sciences and Advanced Technologies "GF Ingrassia", University of Catania, Italy (Piano Triennale di Sviluppo delle Attività di Ricerca Scientifica del Dipartimento 2016-18).

Conflicts of Interest: The authors declare no conflict of interest.

\section{References}

1. Globocan. Globocan 2018: Estimated Cancer Incidence, Mortality and Prevalence Worldwide in 2018. Available online: http://globocan.iarc.fr/Default.aspx (accessed on 1 May 2019).

2. Abubakar, I.I.; Tillmann, T.; Banerjee, A. Global, regional, and national age-sex specific all-cause and cause-specific mortality for 240 causes of death, 1990-2013: A systematic analysis for the Global Burden of Disease Study 2013. Lancet 2015, 385, 117-171. [CrossRef]

3. Hanahan, D.; Weinberg, R.A. The hallmarks of cancer. Cell 2000, 100, 57-70. [CrossRef] 
4. Hanahan, D.; Weinberg, R.A. Hallmarks of cancer: The next generation. Cell 2011, 144, 646-674. [CrossRef] [PubMed]

5. Jubb, A.M.; Bell, S.M.; Quirke, P. Methylation and colorectal cancer. J. Pathol. 2001, 195, 111-134. [CrossRef] [PubMed]

6. Jubb, A.M.; Quirke, P.; Oates, A.J. DNA methylation, a biomarker for colorectal cancer: Implications for screening and pathological utility. Ann. N. Y. Acad. Sci. 2003, 983, 251-267. [CrossRef] [PubMed]

7. Lao, V.V.; Grady, W.M. Epigenetics and colorectal cancer. Nat. Rev. Gastroenterol. Hepatol. 2011, 8, 686-700. [CrossRef] [PubMed]

8. Kim, Y.H.; Petko, Z.; Dzieciatkowski, S.; Lin, L.; Ghiassi, M.; Stain, S.; Chapman, W.C.; Washington, M.K.; Willis, J.; Markowitz, S.D.; et al. CpG island methylation of genes accumulates during the adenoma progression step of the multistep pathogenesis of colorectal cancer. Genes Chromosom. Cancer 2006, 45, 781-789. [CrossRef] [PubMed]

9. Hammoud, S.S.; Cairns, B.R.; Jones, D.A. Epigenetic regulation of colon cancer and intestinal stem cells. Curr. Opin. Cell Biol. 2013, 25, 177-183. [CrossRef] [PubMed]

10. Auclair, G.; Weber, M. Mechanisms of DNA methylation and demethylation in mammals. Biochimie 2012, 94, 2202-2211. [CrossRef]

11. Worthley, D.L.; Whitehall, V.L.; Buttenshaw, R.L.; Irahara, N.; Greco, S.A.; Ramsnes, I.; Mallitt, K.A.; Le Leu, R.K.; Winter, J.; Hu, Y.; et al. DNA methylation within the normal colorectal mucosa is associated with pathway-specific predisposition to cancer. Oncogene 2010, 29, 1653-1662. [CrossRef]

12. Guo, H.; Ingolia, N.T.; Weissman, J.S.; Bartel, D.P. Mammalian microRNAs predominantly act to decrease target mRNA levels. Nature 2010, 466, 835-840. [CrossRef] [PubMed]

13. Bartel, D.P. MicroRNAs: Genomics, biogenesis, mechanism, and function. Cell 2004, 116, 281-297. [CrossRef]

14. Sayed, D.; Abdellatif, M. MicroRNAs in development and disease. Physiol. Rev. 2011, 91, 827-887. [CrossRef] [PubMed]

15. Barchitta, M.; Maugeri, A.; Quattrocchi, A.; Agrifoglio, O.; Agodi, A. The Role of miRNAs as Biomarkers for Pregnancy Outcomes: A Comprehensive Review. Int. J. Genom. 2017, 2017, 8067972. [CrossRef] [PubMed]

16. Rapado-González, Ó.; Álvarez-Castro, A.; López-López, R.; Iglesias-Canle, J.; Suárez-Cunqueiro, M.M.; Muinelo-Romay, L. Circulating microRNAs as Promising Biomarkers in Colorectal Cancer. Cancers 2019, 11, 898. [CrossRef] [PubMed]

17. Fearon, E.R.; Vogelstein, B. A genetic model for colorectal tumorigenesis. Cell 1990, 61, 759-767. [CrossRef]

18. Lengauer, C.; Kinzler, K.W.; Vogelstein, B. Genetic instabilities in human cancers. Nature 1998, 396, 643-649. [CrossRef] [PubMed]

19. Kinzler, K.W.; Vogelstein, B. Lessons from hereditary colorectal cancer. Cell 1996, 87, 159-170. [CrossRef]

20. Feinberg, A.P.; Tycko, B. The history of cancer epigenetics. Nat. Rev. Cancer 2004, 4, 143-153. [CrossRef]

21. Sawan, C.; Herceg, Z. Histone modifications and cancer. Adv. Genet. 2010, 70, 57-85. [CrossRef]

22. Van Engeland, M.; Derks, S.; Smits, K.M.; Meijer, G.A.; Herman, J.G. Colorectal cancer epigenetics: Complex simplicity. J. Clin. Oncol. 2011, 29, 1382-1391. [CrossRef] [PubMed]

23. Kuipers, E.J.; Grady, W.M.; Lieberman, D.; Seufferlein, T.; Sung, J.J.; Boelens, P.G.; van de Velde, C.J.; Watanabe, T. Colorectal cancer. Nat. Rev. Dis. Prim. 2015, 1, 15065. [CrossRef] [PubMed]

24. Labianca, R.; Nordlinger, B.; Beretta, G.D.; Mosconi, S.; Mandalà, M.; Cervantes, A.; Arnold, D.; Group, E.G.W. Early colon cancer: ESMO Clinical Practice Guidelines for diagnosis, treatment and follow-up. Ann. Oncol. 2013, 24, vi64-vi72. [CrossRef] [PubMed]

25. Van Cutsem, E.; Cervantes, A.; Nordlinger, B.; Arnold, D.; Group, E.G.W. Metastatic colorectal cancer: ESMO Clinical Practice Guidelines for diagnosis, treatment and follow-up. Ann. Oncol. 2014, 25, iii1-iii9. [CrossRef] [PubMed]

26. Juul, T.; Ahlberg, M.; Biondo, S.; Emmertsen, K.J.; Espin, E.; Jimenez, L.M.; Matzel, K.E.; Palmer, G.; Sauermann, A.; Trenti, L.; et al. International validation of the low anterior resection syndrome score. Ann. Surg. 2014, 259, 728-734. [CrossRef] [PubMed]

27. Bregendahl, S.; Emmertsen, K.J.; Lindegaard, J.C.; Laurberg, S. Urinary and sexual dysfunction in women after resection with and without preoperative radiotherapy for rectal cancer: A population-based cross-sectional study. Colorectal Dis. 2015, 17, 26-37. [CrossRef] [PubMed] 
28. Gilbert, A.; Ziegler, L.; Martland, M.; Davidson, S.; Efficace, F.; Sebag-Montefiore, D.; Velikova, G. Systematic Review of Radiation Therapy Toxicity Reporting in Randomized Controlled Trials of Rectal Cancer: A Comparison of Patient-Reported Outcomes and Clinician Toxicity Reporting. Int. J. Radiat. Oncol. Biol. Phys. 2015, 92, 555-567. [CrossRef]

29. Williamson, J.S.; Harris, D.A.; Beynon, J.; Jenkins, G.J. Review of the development of DNA methylation as a marker of response to neoadjuvant therapy and outcomes in rectal cancer. Clin. Epigenet. 2015, 7, 70. [CrossRef]

30. Dayde, D.; Tanaka, I.; Jain, R.; Tai, M.C.; Taguchi, A. Predictive and Prognostic Molecular Biomarkers for Response to Neoadjuvant Chemoradiation in Rectal Cancer. Int. J. Mol. Sci. 2017, 18, 573. [CrossRef]

31. Moher, D.; Shamseer, L.; Clarke, M.; Ghersi, D.; Liberati, A.; Petticrew, M.; Shekelle, P.; Stewart, L.A.; Group, P.P. Preferred reporting items for systematic review and meta-analysis protocols (PRISMA-P) 2015 statement. Syst. Rev. 2015, 4, 1. [CrossRef]

32. Nagasaka, T.; Sharp, G.B.; Notohara, K.; Kambara, T.; Sasamoto, H.; Isozaki, H.; MacPhee, D.G.; Jass, J.R.; Tanaka, N.; Matsubara, N. Hypermethylation of O6-methylguanine-DNA methyltransferase promoter may predict nonrecurrence after chemotherapy in colorectal cancer cases. Clin. Cancer Res. 2003, 9, 5306-5312. [PubMed]

33. Chen, S.P.; Chiu, S.C.; Wu, C.C.; Lin, S.Z.; Kang, J.C.; Chen, Y.L.; Lin, P.C.; Pang, C.Y.; Harn, H.J. The association of methylation in the promoter of APC and MGMT and the prognosis of Taiwanese CRC patients. Genet. Test. Mol. Biomark. 2009, 13, 67-71. [CrossRef] [PubMed]

34. Miyoshi, Y.; Nagase, H.; Ando, H.; Horii, A.; Ichii, S.; Nakatsuru, S.; Aoki, T.; Miki, Y.; Mori, T.; Nakamura, Y. Somatic mutations of the APC gene in colorectal tumors: Mutation cluster region in the APC gene. Hum. Mol. Genet. 1992, 1, 229-233. [PubMed]

35. Ide, T.; Kitajima, Y.; Ohtaka, K.; Mitsuno, M.; Nakafusa, Y.; Miyazaki, K. Expression of the hMLH1 gene is a possible predictor for the clinical response to 5-fluorouracil after a surgical resection in colorectal cancer. Oncol. Rep. 2008, 19, 1571-1576. [PubMed]

36. Sinicrope, F.A.; Shi, Q.; Smyrk, T.C.; Thibodeau, S.N.; Dienstmann, R.; Guinney, J.; Bot, B.M.; Tejpar, S.; Delorenzi, M.; Goldberg, R.M.; et al. Molecular markers identify subtypes of stage III colon cancer associated with patient outcomes. Gastroenterology 2015, 148, 88-99. [CrossRef]

37. Perez-Carbonell, L.; Balaguer, F.; Toiyama, Y.; Egoavil, C.; Rojas, E.; Guarinos, C.; Andreu, M.; Llor, X.; Castells, A.; Jover, R.; et al. IGFBP3 methylation is a novel diagnostic and predictive biomarker in colorectal cancer. PLoS ONE 2014, 9, e104285. [CrossRef]

38. Heitzer, E.; Artl, M.; Filipits, M.; Resel, M.; Graf, R.; Weißenbacher, B.; Lax, S.; Gnant, M.; Wrba, F.; Greil, R.; et al. Differential survival trends of stage II colorectal cancer patients relate to promoter methylation status of PCDH10, SPARC, and UCHL1. Mod. Pathol. 2014, 27, 906-915. [CrossRef]

39. Jeanes, A.; Gottardi, C.J.; Yap, A.S. Cadherins and cancer: How does cadherin dysfunction promote tumor progression? Oncogene 2008, 27, 6920-6929. [CrossRef]

40. Ying, J.; Li, H.; Seng, T.J.; Langford, C.; Srivastava, G.; Tsao, S.W.; Putti, T.; Murray, P.; Chan, A.T.; Tao, Q. Functional epigenetics identifies a protocadherin PCDH10 as a candidate tumor suppressor for nasopharyngeal, esophageal and multiple other carcinomas with frequent methylation. Oncogene 2006, 25, 1070-1080. [CrossRef]

41. Li, L.; Tao, Q.; Jin, H.; van Hasselt, A.; Poon, F.F.; Wang, X.; Zeng, M.S.; Jia, W.H.; Zeng, Y.X.; Chan, A.T.; et al. The tumor suppressor UCHL1 forms a complex with p53/MDM2/ARF to promote p53 signaling and is frequently silenced in nasopharyngeal carcinoma. Clin. Cancer Res. 2010, 16, 2949-2958. [CrossRef]

42. Kim, J.H.; Jung, E.J.; Lee, H.S.; Kim, M.A.; Kim, W.H. Comparative analysis of DNA methylation between primary and metastatic gastric carcinoma. Oncol. Rep. 2009, 21, 1251-1259. [CrossRef] [PubMed]

43. Chang, S.Y.; Kuo, C.C.; Wu, C.C.; Hsiao, C.W.; Hu, J.M.; Hsu, C.H.; Chou, Y.C.; Shih, Y.L.; Lin, Y.W. NKX6.1 hypermethylation predicts the outcome of stage II colorectal cancer patients undergoing chemotherapy. Genes Chromosom. Cancer 2018, 57, 268-277. [CrossRef] [PubMed]

44. Chang, C.C.; Huang, R.L.; Wang, H.C.; Liao, Y.P.; Yu, M.H.; Lai, H.C. High methylation rate of LMX1A, NKX6-1, PAX1, PTPRR, SOX1, and ZNF582 genes in cervical adenocarcinoma. Int. J. Gynecol. Cancer 2014, 24, 201-209. [CrossRef] [PubMed] 
45. Taylor, K.H.; Pena-Hernandez, K.E.; Davis, J.W.; Arthur, G.L.; Duff, D.J.; Shi, H.; Rahmatpanah, F.B.; Sjahputera, O.; Caldwell, C.W. Large-scale CpG methylation analysis identifies novel candidate genes and reveals methylation hotspots in acute lymphoblastic leukemia. Cancer Res. 2007, 67, 2617-2625. [CrossRef] [PubMed]

46. Asada, K.; Nakajima, T.; Shimazu, T.; Yamamichi, N.; Maekita, T.; Yokoi, C.; Oda, I.; Ando, T.; Yoshida, T.; Nanjo, S.; et al. Demonstration of the usefulness of epigenetic cancer risk prediction by a multicentre prospective cohort study. Gut 2015, 64, 388-396. [CrossRef] [PubMed]

47. Pfütze, K.; Benner, A.; Hoffmeister, M.; Jansen, L.; Yang, R.; Bläker, H.; Herpel, E.; Ulrich, A.; Ulrich, C.M.; Chang-Claude, J.; et al. Methylation status at HYAL2 predicts overall and progression-free survival of colon cancer patients under 5-FU chemotherapy. Genomics 2015, 106, 348-354. [CrossRef] [PubMed]

48. Van Rijnsoever, M.; Elsaleh, H.; Joseph, D.; McCaul, K.; Iacopetta, B. CpG island methylator phenotype is an independent predictor of survival benefit from 5-fluorouracil in stage III colorectal cancer. Clin. Cancer Res. 2003, 9, 2898-2903. [PubMed]

49. Min, B.H.; Bae, J.M.; Lee, E.J.; Yu, H.S.; Kim, Y.H.; Chang, D.K.; Kim, H.C.; Park, C.K.; Lee, S.H.; Kim, K.M.; et al. The $\mathrm{CpG}$ island methylator phenotype may confer a survival benefit in patients with stage II or III colorectal carcinomas receiving fluoropyrimidine-based adjuvant chemotherapy. BMC Cancer 2011, 11, 344. [CrossRef]

50. Shiovitz, S.; Bertagnolli, M.M.; Renfro, L.A.; Nam, E.; Foster, N.R.; Dzieciatkowski, S.; Luo, Y.; Lao, V.V.; Monnat, R.J.; Emond, M.J.; et al. CpG island methylator phenotype is associated with response to adjuvant irinotecan-based therapy for stage III colon cancer. Gastroenterology 2014, 147, 637-645. [CrossRef]

51. Cohen, S.A.; Wu, C.; Yu, M.; Gourgioti, G.; Wirtz, R.; Raptou, G.; Gkakou, C.; Kotoula, V.; Pentheroudakis, G.; Papaxoinis, G.; et al. Evaluation of CpG Island Methylator Phenotype as a Biomarker in Colorectal Cancer Treated with Adjuvant Oxaliplatin. Clin. Colorectal Cancer 2016, 15, 164-169. [CrossRef]

52. Jover, R.; Nguyen, T.P.; Pérez-Carbonell, L.; Zapater, P.; Payá, A.; Alenda, C.; Rojas, E.; Cubiella, J.; Balaguer, F.; Morillas, J.D.; et al. 5-Fluorouracil adjuvant chemotherapy does not increase survival in patients with CpG island methylator phenotype colorectal cancer. Gastroenterology 2011, 140, 1174-1181. [CrossRef] [PubMed]

53. Han, S.W.; Lee, H.J.; Bae, J.M.; Cho, N.Y.; Lee, K.H.; Kim, T.Y.; Oh, D.Y.; Im, S.A.; Bang, Y.J.; Jeong, S.Y.; et al. Methylation and microsatellite status and recurrence following adjuvant FOLFOX in colorectal cancer. Int. J. Cancer 2013, 132, 2209-2216. [CrossRef] [PubMed]

54. Bae, J.M.; Kim, J.H.; Kwak, Y.; Lee, D.W.; Cha, Y.; Wen, X.; Lee, T.H.; Cho, N.Y.; Jeong, S.Y.; Park, K.J.; et al. Distinct clinical outcomes of two CIMP-positive colorectal cancer subtypes based on a revised CIMP classification system. Br. J. Cancer 2017, 116, 1012-1020. [CrossRef] [PubMed]

55. Babatz, T.D.; Burns, K.H. Functional impact of the human mobilome. Curr. Opin. Genet. Dev. 2013, 23, 264-270. [CrossRef] [PubMed]

56. Fabris, S.; Ronchetti, D.; Agnelli, L.; Baldini, L.; Morabito, F.; Bicciato, S.; Basso, D.; Todoerti, K.; Lombardi, L.; Lambertenghi-Deliliers, G.; et al. Transcriptional features of multiple myeloma patients with chromosome 1q gain. Leukemia 2007, 21, 1113-1116. [CrossRef] [PubMed]

57. Carreira, P.E.; Richardson, S.R.; Faulkner, G.J. L1 retrotransposons, cancer stem cells and oncogenesis. FEBS J. 2014, 281, 63-73. [CrossRef]

58. Rodić, N.; Burns, K.H. Long interspersed element-1 (LINE-1): Passenger or driver in human neoplasms? PLoS Genet. 2013, 9, e1003402. [CrossRef] [PubMed]

59. Barchitta, M.; Quattrocchi, A.; Maugeri, A.; Canto, C.; La Rosa, N.; Cantarella, M.A.; Spampinato, G.; Scalisi, A.; Agodi, A. LINE-1 hypermethylation in white blood cell DNA is associated with high-grade cervical intraepithelial neoplasia. BMC Cancer 2017, 17, 601. [CrossRef]

60. Maugeri, A.; Barchitta, M.; Mazzone, M.G.; Giuliano, F.; Basile, G.; Agodi, A. Resveratrol modulates SIRT1 and DNMT functions and restores LINE-1 methylation levels in ARPE-19 cells under oxidative stress and inflammation. Int. J. Mol. Sci. 2018, 19, 2118. [CrossRef]

61. Maugeri, A.; Mazzone, M.G.; Giuliano, F.; Vinciguerra, M.; Basile, G.; Barchitta, M.; Agodi, A. Curcumin Modulates DNA Methyltransferase Functions in a Cellular Model of Diabetic Retinopathy. Oxid. Med. Cell Longev. 2018, 2018, 5407482. [CrossRef]

62. Bollati, V.; Schwartz, J.; Wright, R.; Litonjua, A.; Tarantini, L.; Suh, H.; Sparrow, D.; Vokonas, P.; Baccarelli, A. Decline in genomic DNA methylation through aging in a cohort of elderly subjects. Mech. Ageing Dev. 2009, 130, 234-239. [CrossRef] [PubMed] 
63. Bollati, V.; Galimberti, D.; Pergoli, L.; Dalla Valle, E.; Barretta, F.; Cortini, F.; Scarpini, E.; Bertazzi, P.A.; Baccarelli, A. DNA methylation in repetitive elements and Alzheimer disease. Brain Behav. Immun. 2011, 25, 1078-1083. [CrossRef] [PubMed]

64. Barchitta, M.; Quattrocchi, A.; Maugeri, A.; Vinciguerra, M.; Agodi, A. LINE-1 hypomethylation in blood and tissue samples as an epigenetic marker for cancer risk: A systematic review and meta-analysis. PLoS ONE 2014, 9, e109478. [CrossRef] [PubMed]

65. Agodi, A.; Barchitta, M.; Quattrocchi, A.; Maugeri, A.; Canto, C.; Marchese, A.E.; Vinciguerra, M. Low fruit consumption and folate deficiency are associated with LINE-1 hypomethylation in women of a cancer-free population. Genes Nutr. 2015, 10, 480. [CrossRef] [PubMed]

66. Barchitta, M.; Maugeri, A.; Quattrocchi, A.; Barone, G.; Mazzoleni, P.; Catalfo, A.; De Guidi, G.; Iemmolo, M.G.; Crimi, N.; Agodi, A. Mediterranean Diet and Particulate Matter Exposure Are Associated With LINE-1 Methylation: Results From a Cross-Sectional Study in Women. Front. Genet. 2018, 9, 514. [CrossRef]

67. Baccarelli, A.; Wright, R.O.; Bollati, V.; Tarantini, L.; Litonjua, A.A.; Suh, H.H.; Zanobetti, A.; Sparrow, D.; Vokonas, P.S.; Schwartz, J. Rapid DNA methylation changes after exposure to traffic particles. Am. J. Respir. Crit. Care Med. 2009, 179, 572-578. [CrossRef]

68. De Prins, S.; Koppen, G.; Jacobs, G.; Dons, E.; Van de Mieroop, E.; Nelen, V.; Fierens, F.; Int Panis, L.; De Boever, P.; Cox, B.; et al. Influence of ambient air pollution on global DNA methylation in healthy adults: A seasonal follow-up. Environ. Int. 2013, 59, 418-424. [CrossRef]

69. Schulz, W.A. L1 retrotransposons in human cancers. J. Biomed. Biotechnol. 2006, 2006, 83672. [CrossRef]

70. Slotkin, R.K.; Martienssen, R. Transposable elements and the epigenetic regulation of the genome. Nat. Rev. Genet. 2007, 8, 272-285. [CrossRef]

71. Kawakami, K.; Matsunoki, A.; Kaneko, M.; Saito, K.; Watanabe, G.; Minamoto, T. Long interspersed nuclear element-1 hypomethylation is a potential biomarker for the prediction of response to oral fluoropyrimidines in microsatellite stable and CpG island methylator phenotype-negative colorectal cancer. Cancer Sci. 2011, 102, 166-174. [CrossRef]

72. Ogino, S.; Kawasaki, T.; Nosho, K.; Ohnishi, M.; Suemoto, Y.; Kirkner, G.J.; Fuchs, C.S. LINE-1 hypomethylation is inversely associated with microsatellite instability and $\mathrm{CpG}$ island methylator phenotype in colorectal cancer. Int. J. Cancer 2008, 122, 2767-2773. [CrossRef] [PubMed]

73. Chen, D.; Wen, X.; Song, Y.S.; Rhee, Y.Y.; Lee, T.H.; Cho, N.Y.; Han, S.W.; Kim, T.Y.; Kang, G.H. Associations and prognostic implications of Eastern Cooperative Oncology Group performance status and tumoral LINE-1 methylation status in stage III colon cancer patients. Clin. Epigenet. 2016, 8, 36. [CrossRef] [PubMed]

74. Lou, Y.T.; Chen, C.W.; Fan, Y.C.; Chang, W.C.; Lu, C.Y.; Wu, I.C.; Hsu, W.H.; Huang, C.W.; Wang, J.Y. LINE-1 Methylation Status Correlates Significantly to Post-Therapeutic Recurrence in Stage III Colon Cancer Patients Receiving FOLFOX-4 Adjuvant Chemotherapy. PLoS ONE 2014, 10, e0123973. [CrossRef] [PubMed]

75. De Maat, M.F.; van de Velde, C.J.; Benard, A.; Putter, H.; Morreau, H.; van Krieken, J.H.; Meershoek Klein-Kranenbarg, E.; de Graaf, E.J.; Tollenaar, R.A.; Hoon, D.S. Identification of a quantitative MINT locus methylation profile predicting local regional recurrence of rectal cancer. Clin. Cancer Res. 2010, 16, 2811-2818. [CrossRef] [PubMed]

76. Ebert, M.P.; Tänzer, M.; Balluff, B.; Burgermeister, E.; Kretzschmar, A.K.; Hughes, D.J.; Tetzner, R.; Lofton-Day, C.; Rosenberg, R.; Reinacher-Schick, A.C.; et al. TFAP2E-DKK4 and chemoresistance in colorectal cancer. N. Engl. J. Med. 2012, 366, 44-53. [CrossRef] [PubMed]

77. Molinari, C.; Casadio, V.; Foca, F.; Zingaretti, C.; Giannini, M.; Avanzolini, A.; Lucci, E.; Saragoni, L.; Passardi, A.; Amadori, D.; et al. Gene methylation in rectal cancer: Predictive marker of response to chemoradiotherapy? J. Cell. Physiol. 2013, 228, 2343-2349. [CrossRef] [PubMed]

78. Sun, W.; Sun, Y.; Zhu, M.; Wang, Z.; Zhang, H.; Xin, Y.; Jiang, G.; Guo, X.; Zhang, Z.; Liu, Y. The role of plasma cell-free DNA detection in predicting preoperative chemoradiotherapy response in rectal cancer patients. Oncol. Rep. 2014, 31, 1466-1472. [CrossRef] [PubMed]

79. Jo, P.; Jung, K.; Grade, M.; Conradi, L.C.; Wolff, H.A.; Kitz, J.; Becker, H.; Rüschoff, J.; Hartmann, A.; Beissbarth, T.; et al. CpG island methylator phenotype infers a poor disease-free survival in locally advanced rectal cancer. Surgery 2012, 151, 564-570. [CrossRef]

80. Kohonen-Corish, M.R.; Tseung, J.; Chan, C.; Currey, N.; Dent, O.F.; Clarke, S.; Bokey, L.; Chapuis, P.H. KRAS mutations and CDKN2A promoter methylation show an interactive adverse effect on survival and predict recurrence of rectal cancer. Int. J. Cancer 2014, 134, 2820-2828. [CrossRef] 
81. Tsang, J.S.; Vencken, S.; Sharaf, O.; Leen, E.; Kay, E.W.; McNamara, D.A.; Deasy, J.; Mulligan, E.D. Global DNA methylation is altered by neoadjuvant chemoradiotherapy in rectal cancer and may predict response to treatment-A pilot study. Eur. J. Surg. Oncol. 2014, 40, 1459-1466. [CrossRef]

82. Gaedcke, J.; Leha, A.; Claus, R.; Weichenhan, D.; Jung, K.; Kitz, J.; Grade, M.; Wolff, H.A.; Jo, P.; Doyen, J.; et al. Identification of a DNA methylation signature to predict disease-free survival in locally advanced rectal cancer. Oncotarget 2014, 5, 8123-8135. [CrossRef] [PubMed]

83. Schetter, A.J.; Leung, S.Y.; Sohn, J.J.; Zanetti, K.A.; Bowman, E.D.; Yanaihara, N.; Yuen, S.T.; Chan, T.L.; Kwong, D.L.; Au, G.K.; et al. MicroRNA expression profiles associated with prognosis and therapeutic outcome in colon adenocarcinoma. JAMA 2008, 299, 425-436. [CrossRef] [PubMed]

84. Oue, N.; Anami, K.; Schetter, A.J.; Moehler, M.; Okayama, H.; Khan, M.A.; Bowman, E.D.; Mueller, A.; Schad, A.; Shimomura, M.; et al. High miR-21 expression from FFPE tissues is associated with poor survival and response to adjuvant chemotherapy in colon cancer. Int. J. Cancer 2014, 134, 1926-1934. [CrossRef] [PubMed]

85. Coebergh van den Braak, R.R.J.; Sieuwerts, A.M.; Lalmahomed, Z.S.; Smid, M.; Wilting, S.M.; Bril, S.I.; Xiang, S.; van der Vlugt-Daane, M.; de Weerd, V.; van Galen, A.; et al. Confirmation of a metastasis-specific microRNA signature in primary colon cancer. Sci. Rep. 2018, 8, 5242. [CrossRef] [PubMed]

86. Ma, Y.; Zhang, P.; Wang, F.; Zhang, H.; Yang, J.; Peng, J.; Liu, W.; Qin, H. miR-150 as a potential biomarker associated with prognosis and therapeutic outcome in colorectal cancer. Gut 2012, 61, 1447-1453. [CrossRef] [PubMed]

87. Perez-Carbonell, L.; Sinicrope, F.A.; Alberts, S.R.; Oberg, A.L.; Balaguer, F.; Castells, A.; Boland, C.R.; Goel, A. MiR-320e is a novel prognostic biomarker in colorectal cancer. Br. J. Cancer 2015, 113, 83-90. [CrossRef] [PubMed]

88. Zhang, J.X.; Song, W.; Chen, Z.H.; Wei, J.H.; Liao, Y.J.; Lei, J.; Hu, M.; Chen, G.Z.; Liao, B.; Lu, J.; et al. Prognostic and predictive value of a microRNA signature in stage II colon cancer: A microRNA expression analysis. Lancet Oncol. 2013, 14, 1295-1306. [CrossRef]

89. To, K.K.; Leung, W.W.; Ng, S.S. Exploiting a novel miR-519c-HuR-ABCG2 regulatory pathway to overcome chemoresistance in colorectal cancer. Exp. Cell Res. 2015, 338, 222-231. [CrossRef]

90. Diaz, T.; Tejero, R.; Moreno, I.; Ferrer, G.; Cordeiro, A.; Artells, R.; Navarro, A.; Hernandez, R.; Tapia, G.; Monzo, M. Role of miR-200 family members in survival of colorectal cancer patients treated with fluoropyrimidines. J. Surg. Oncol. 2014, 109, 676-683. [CrossRef]

91. Li, S.; Gao, J.; Gu, J.; Yuan, J.; Hua, D.; Shen, L. MicroRNA-215 inhibits relapse of colorectal cancer patients following radical surgery. Med. Oncol. 2013, 30, 549. [CrossRef]

92. Dou, R.; Deng, Y.; Huang, L.; Fu, S.; Tan, S.; Wang, L.; Lian, L.; Fang, L.; Fan, X.; Jin, G.; et al. Multi-microarray identifies lower AQP9 expression in adjuvant chemotherapy nonresponders with stage III colorectal cancer. Cancer Lett. 2013, 336, 106-113. [CrossRef] [PubMed]

93. Conev, N.V.; Donev, I.S.; Konsoulova-Kirova, A.A.; Chervenkov, T.G.; Kashlov, J.K.; Ivanov, K.D. Serum expression levels of miR-17, miR-21, and miR-92 as potential biomarkers for recurrence after adjuvant chemotherapy in colon cancer patients. Biosci. Trends 2015, 9, 393-401. [CrossRef] [PubMed]

94. Liu, C.; Eng, C.; Shen, J.; Lu, Y.; Takata, Y.; Mehdizadeh, A.; Chang, G.J.; Rodriguez-Bigas, M.A.; Li, Y.; Chang, P.; et al. Serum exosomal miR-4772-3p is a predictor of tumor recurrence in stage II and III colon cancer. Oncotarget 2016, 7, 76250-76260. [CrossRef] [PubMed]

95. Gaedcke, J.; Grade, M.; Camps, J.; Søkilde, R.; Kaczkowski, B.; Schetter, A.J.; Difilippantonio, M.J.; Harris, C.C.; Ghadimi, B.M.; Møller, S.; et al. The rectal cancer microRNAome-Microrna expression in rectal cancer and matched normal mucosa. Clin. Cancer Res. 2012, 18, 4919-4930. [CrossRef] [PubMed]

96. Drebber, U.; Lay, M.; Wedemeyer, I.; Vallböhmer, D.; Bollschweiler, E.; Brabender, J.; Mönig, S.P.; Hölscher, A.H.; Dienes, H.P.; Odenthal, M. Altered levels of the onco-microRNA 21 and the tumor-supressor microRNAs 143 and 145 in advanced rectal cancer indicate successful neoadjuvant chemoradiotherapy. Int. J. Oncol. 2011, 39, 409-415. [CrossRef] [PubMed]

97. Svoboda, M.; Sana, J.; Fabian, P.; Kocakova, I.; Gombosova, J.; Nekvindova, J.; Radova, L.; Vyzula, R.; Slaby, O. MicroRNA expression profile associated with response to neoadjuvant chemoradiotherapy in locally advanced rectal cancer patients. Radiat. Oncol. 2012, 7, 195. [CrossRef] [PubMed] 
98. Kheirelseid, E.A.; Miller, N.; Chang, K.H.; Curran, C.; Hennessey, E.; Sheehan, M.; Newell, J.; Lemetre, C.; Balls, G.; Kerin, M.J. miRNA expressions in rectal cancer as predictors of response to neoadjuvant chemoradiation therapy. Int. J. Colorectal Dis. 2013, 28, 247-260. [CrossRef]

99. Della Vittoria Scarpati, G.; Falcetta, F.; Carlomagno, C.; Ubezio, P.; Marchini, S.; De Stefano, A.; Singh, V.K.; D'Incalci, M.; De Placido, S.; Pepe, S. A specific miRNA signature correlates with complete pathological response to neoadjuvant chemoradiotherapy in locally advanced rectal cancer. Int. J. Radiat. Oncol. Biol. Phys. 2012, 83, 1113-1119. [CrossRef]

100. Campayo, M.; Navarro, A.; Benítez, J.C.; Santasusagna, S.; Ferrer, C.; Monzó, M.; Cirera, L. miR-21, miR-99b and miR-375 combination as predictive response signature for preoperative chemoradiotherapy in rectal cancer. PLoS ONE 2018, 13, e0206542. [CrossRef]

101. Lopes-Ramos, C.M.; Habr-Gama, A.; Quevedo, B.e.S.; Felício, N.M.; Bettoni, F.; Koyama, F.C.; Asprino, P.F.; Galante, P.A.; Gama-Rodrigues, J.; Camargo, A.A.; et al. Overexpression of miR-21-5p as a predictive marker for complete tumor regression to neoadjuvant chemoradiotherapy in rectal cancer patients. BMC Med. Genom. 2014, 7, 68. [CrossRef]

102. Caramés, C.; Cristobal, I.; Moreno, V.; Marín, J.P.; González-Alonso, P.; Torrejón, B.; Minguez, P.; Leon, A.; Martín, J.I.; Hernández, R.; et al. MicroRNA-31 Emerges as a Predictive Biomarker of Pathological Response and Outcome in Locally Advanced Rectal Cancer. Int. J. Mol. Sci. 2016, 17, 878. [CrossRef] [PubMed]

103. D'Angelo, E.; Zanon, C.; Sensi, F.; Digito, M.; Rugge, M.; Fassan, M.; Scarpa, M.; Pucciarelli, S.; Nitti, D.; Agostini, M. miR-194 as predictive biomarker of responsiveness to neoadjuvant chemoradiotherapy in patients with locally advanced rectal adenocarcinoma. J. Clin. Pathol. 2018, 71, 344-350. [CrossRef] [PubMed]

104. Du, B.; Wang, X.; Wu, D.; Wang, T.; Yang, X.; Wang, J.; Shi, X.; Chen, L.; Zhang, W. MicroRNA expression profiles identify biomarkers for predicting the response to chemoradiotherapy in rectal cancer. Mol. Med. Rep. 2018, 18, 1909-1916. [CrossRef] [PubMed]

105. Luo, J.; Liu, L.; Zhou, N.; Shen, J.; Sun, Q.; Zhu, Y.; Chen, M. miR-519b-3p promotes responsiveness to preoperative chemoradiotherapy in rectal cancer patients by targeting ARID4B. Gene 2018, 655, 84-90. [CrossRef] [PubMed]

106. Yu, J.; Li, N.; Wang, X.; Ren, H.; Wang, W.; Wang, S.; Song, Y.; Liu, Y.; Li, Y.; Zhou, X.; et al. Circulating serum microRNA-345 correlates with unfavorable pathological response to preoperative chemoradiotherapy in locally advanced rectal cancer. Oncotarget 2016, 7, 64233-64243. [CrossRef] [PubMed]

107. Menéndez, P.; Padilla, D.; Villarejo, P.; Palomino, T.; Nieto, P.; Menéndez, J.M.; Rodríguez-Montes, J.A. Prognostic implications of serum microRNA-21 in colorectal cancer. J. Surg. Oncol. 2013, 108, 369-373. [CrossRef]

108. Hiyoshi, Y.; Akiyoshi, T.; Inoue, R.; Murofushi, K.; Yamamoto, N.; Fukunaga, Y.; Ueno, M.; Baba, H.; Mori, S.; Yamaguchi, T. Serum miR-143 levels predict the pathological response to neoadjuvant chemoradiotherapy in patients with locally advanced rectal cancer. Oncotarget 2017, 8, 79201-79211. [CrossRef]

109. Toyota, M.; Ahuja, N.; Ohe-Toyota, M.; Herman, J.G.; Baylin, S.B.; Issa, J.P. CpG island methylator phenotype in colorectal cancer. Proc. Natl. Acad. Sci. USA 1999, 96, 8681-8686. [CrossRef]

110. Berg, M.; Hagland, H.R.; Søreide, K. Comparison of CpG island methylator phenotype (CIMP) frequency in colon cancer using different probe- and gene-specific scoring alternatives on recommended multi-gene panels. PLOS ONE 2014, 9, e86657. [CrossRef]

111. Sottoriva, A.; Kang, H.; Ma, Z.; Graham, T.A.; Salomon, M.P.; Zhao, J.; Marjoram, P.; Siegmund, K.; Press, M.F.; Shibata, D.; et al. A Big Bang model of human colorectal tumor growth. Nat. Genet. 2015, 47, $209-216$. [CrossRef]

(C) 2019 by the authors. Licensee MDPI, Basel, Switzerland. This article is an open access article distributed under the terms and conditions of the Creative Commons Attribution (CC BY) license (http://creativecommons.org/licenses/by/4.0/). 